\title{
Myctophid Feeding Ecology and Carbon Transport along the Northern Mid-Atlantic Ridge
}

Jeanna M. Hudson

College of William and Mary - Virginia Institute of Marine Science

Follow this and additional works at: https://scholarworks.wm.edu/etd

Part of the Marine Biology Commons, and the Oceanography Commons

\section{Recommended Citation}

Hudson, Jeanna M., "Myctophid Feeding Ecology and Carbon Transport along the Northern Mid-Atlantic Ridge" (2012). Dissertations, Theses, and Masters Projects. Paper 1539617916.

https://dx.doi.org/doi:10.25773/v5-ej71-b861

This Thesis is brought to you for free and open access by the Theses, Dissertations, \& Master Projects at W\&M ScholarWorks. It has been accepted for inclusion in Dissertations, Theses, and Masters Projects by an authorized administrator of W\&M ScholarWorks. For more information, please contact scholarworks@wm.edu. 
Myctophid Feeding Ecology and Carbon Transport along the Northern Mid-Atlantic

Ridge

\author{
A Thesis \\ Presented to \\ The Faculty of the School of Marine Science \\ The College of William and Mary in Virginia
}

In Partial Fulfillment

of the Requirements for the Degree of

Master of Science

by

Jeanna M. Hudson

2012 


\section{APPROVAL SHEET}

This thesis is submitted in partial fulfillment of the requirements for the degree of

\section{Master of Science}

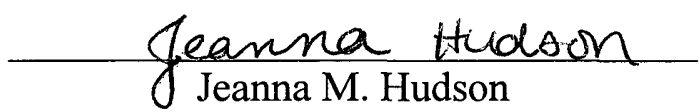

Approved by the Committee October 22, 2012

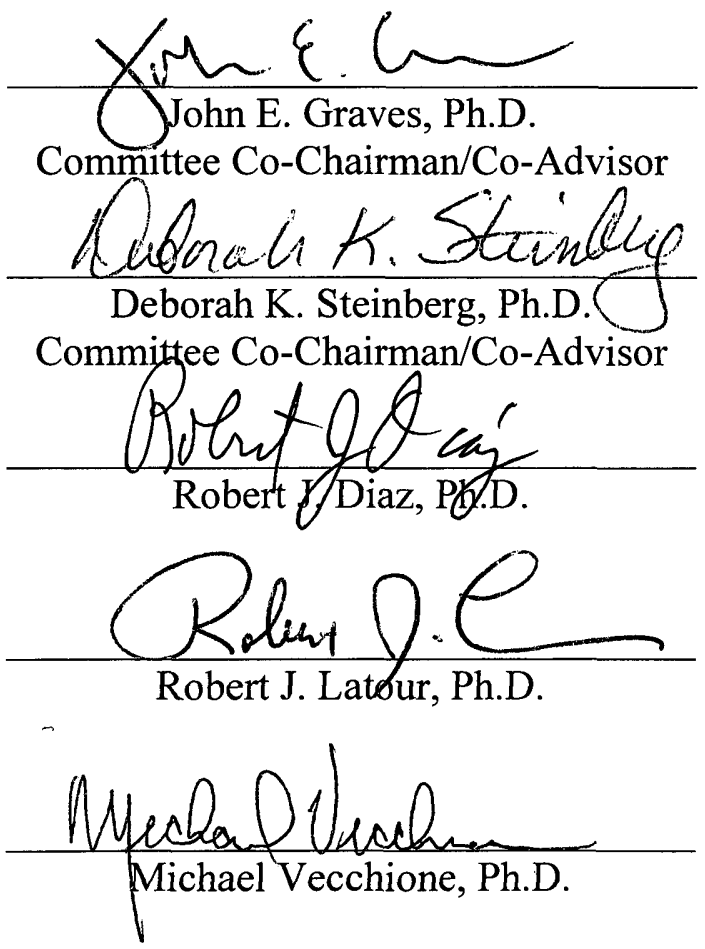




\section{TABLE OF CONTENTS}

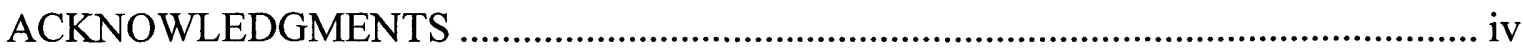

LIST OF TABLES

LIST OF FIGURES

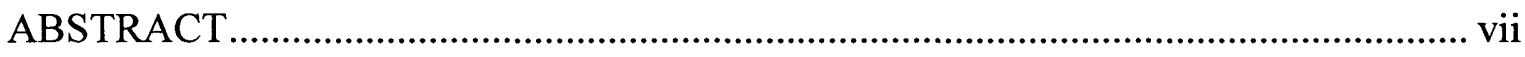

INTRODUCTION

Myctophid ecology and potential role in carbon export .............................................

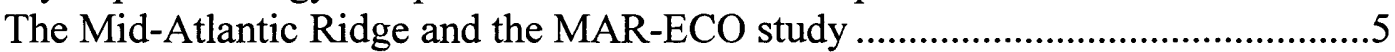

Pelagic fish community structure of the Mid-Atlantic Ridge ..................................

Objectives and significance of the study ..............................................................

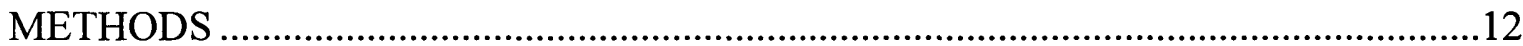

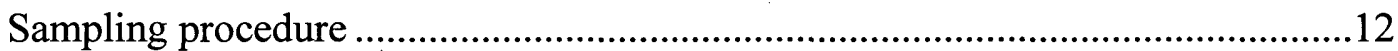

Myctophid selection, dissection, and prey identification.......................................12

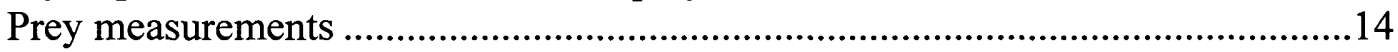

General diet description ......................................................................................14

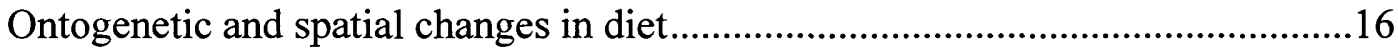

Gastric evacuation and daily consumption .............................................................17

Active carbon export by diel vertical migration .......................................................17

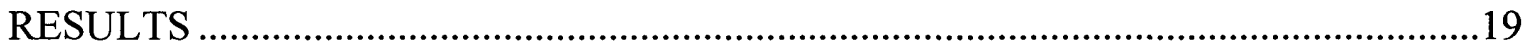

General diet description .....................................................................................19

Ontogenetic and spatial changes in diet..........................................................20

Species interaction and the effect on spatial changes in diet..................................23

Gastric evacuation and daily consumption ..............................................................24

Active carbon export by diel vertical migration .....................................................25

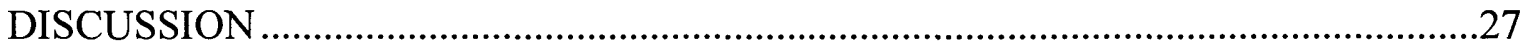

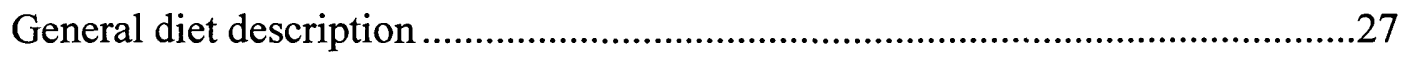

Ontogenetic and spatial changes in diet...............................................................31

Daily consumption ..............................................................................................37

Active carbon export by diel vertical migration ....................................................40

CONCLUSION

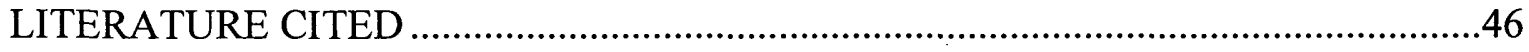

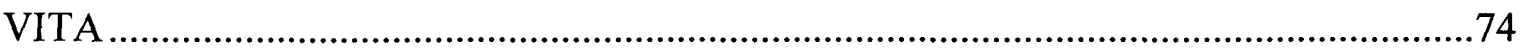




\section{ACKNOWLEDGMENTS}

I am very grateful to Dr. Odd Aksel Bergstad and the members of the MAR-ECO program, without whom this work would not have been possible. I would like to especially thank Ingvar Byrkjedal for his assistance in deciphering museum specimen catalogs and for packaging and shipping myctophid samples. I am very appreciative to Dr. Tracey Sutton for providing me the opportunity to work with MAR-ECO and giving me my start in the field of deep-sea science.

I would like to thank my co-advisors, Dr. John Graves and Dr. Debbie Steinberg, for their support and willingness to help me succeed. John, thank you for the personal interest you took in my success and your constant encouragement. Your coaching for oral exams and record-breaking turn-around times for edits are truly appreciated. Debbie, thank you for pushing me to expand my thesis into the world of carbon. I truly feel it has positively contributed to my thesis and to the area of study. Your enthusiasm is infectious and could bring a smile to my face no matter how many hours I had spent on the microscope. Many thanks to Dr. Rob Latour for the countless hours of statistical guidance and his unwavering patience with me as I tried to keep up. I am so appreciative of your dedication to this project. To my remaining committee members, Dr. Mike Vecchione and Dr. Bob Diaz, thank you for your invaluable insight, comments, and discussions. I am very appreciative to Dr. Kam Tang for allowing me to use his lab space and equipment. Thank you to Dr. Linda Schaffner and the Office of the Associate Dean of Academic Studies for your support, in more ways than one. I am so thankful for everything you all have done for me.

They say it takes a village to raise a child, and I am now certain that it also takes a village to complete a master's thesis. There are so many fellow students who have helped me along the way and to whom I am very thankful. I was lucky enough to belong to two labs and have double the support and friendship of my lab mates. Thank you all for everything from presentation critiques and job advice, to lab dinners and canning adventures. Kristene Parsons and CJ Sweetman, you both have been such a source of support during my time at VIMS, and I am so lucky to be able to call you friends. A big thank you to Catarina Wor, Andre Buchheister, and Patrick Lynch for their invaluable statistical and $\mathrm{R}$ coding knowledge. And to the rest of my friends, we all helped to keep each other sane during this period of our lives, and I am thankful to have met every one of you!

Finally, I owe, perhaps, the most thanks to my mother, Carol Miller, who always knew what I was capable of and refused to settle for less. Thank you for the love and the sacrifices it took to get me to where I am today. Thank you to my Grandpa, Joseph Voss, for all of his interest in my project and for the motivation to keep putting one fish in front of the other so that I could, at last, tell him, "Yes, I am finally finished with my fish!". To the rest of my family, thank you for your support throughout this journey. And finally, my husband, Wes Hudson, I could not have done this without you by my side. You have helped me in so many ways and I am forever grateful for your unconditional love. 


\section{LIST OF TABLES}

Table

1. Diet composition of Benthosema glaciale, Protomyctophum arcticum, and Hygophum hygomii ............................................................................................................. 55-57

2. Daily consumption and gut evacuation rates of Benthosema glaciale,

Protomyctophum arcticum, and Hygophum hygomii.

3. Active carbon transport by diel vertically migrating myctophids from the Mid-Atlantic Ridge. 59

4. Proportion of prey in diets of Benthosema glaciale and Protomyctophum arcticum caught simultaneously. 


\section{LIST OF FIGURES}

Figure

Page

1. Trawl sampling stations along the northern Mid-Atlantic Ridge during leg 1 of the

R/V G.O. Sars MAR-ECO expedition

2. Standard length distribution of Benthosema glaciale, Protomyctophum arcticum, and

Hygophum hygomii

3. Cluster diagram (A) and scree plot (B) for Benthosema glaciale .64

4. Canonical correspondence analysis biplot for Benthosema glaciale

5. Diet composition of Benthosema glaciale by ridge section (A) and time of day

(B) 68-69

6. Canonical correspondence analysis biplot for Protomyctophum arcticum 70

7. Diet composition of Protomyctophum arcticum by depth zone .71

8. Canonical correspondence analysis of Benthosema glaciale and Protomyctophum arcticum including all samples (A) and only samples collected simultaneously (B)..73 


\begin{abstract}
The Mid-Atlantic Ridge (MAR) is the largest topographic feature in the Atlantic Ocean, yet little is known about the food web structure and trophic ecology of fishes inhabiting mesopelagic waters along the MAR. To better understand the food web structure and to compare the feeding ecology of abundant MAR fishes to those in offridge areas, MAR-ECO, a Mid-Atlantic Ridge ecosystem field project of the Census of Marine Life, sampled the pelagic fauna of the northern MAR (Iceland to the Azores) during June-July, 2004. Samples were collected with two midwater trawls outfitted with multiple opening and closing cod ends to sample discrete depths from the surface to $>2300 \mathrm{~m}$ at predefined stations within four ridge sections. Fishes of the family Myctophidae were the most abundant fishes collected, with the myctophid Benthosema glaciale the numerically dominant species. The feeding ecology of three myctophid species, B. glaciale, Protomyctophum arcticum, and Hygophum hygomii, were quantified through dietary analysis. Each species was predominantly zooplanktivorous, consuming copepods, euphausiids, ostracods, and other crustacean zooplankton, with each myctophid species exhibiting unique dietary patterns. Different abiotic parameters influenced variability in the diet of $B$. glaciale and $P$. arcticum as determined by canonical correspondence analysis. Of the measured parameters, ridge section and time of day were significant explanatory variables in the diet of $B$. glaciale, while only depth was significant in the diet of $P$. arcticum. Daily consumption by $B$. glaciale and $P$. arcticum was highest at the Reykjanes Ridge and Charlie-Gibbs Fracture Zone, respectively; consumption by $H$. hygomii was only measured at the Azorean Zone. Daily consumption of all three species was less than $1 \%$ of dry body weight. Active transport
\end{abstract}


of carbon out of the euphotic zone by diel vertically migrating MAR myctophids through respiration of $\mathrm{CO}_{2}$, excretion of dissolved organic carbon, and egestion of particulate organic carbon (POC) was also estimated, and compared to passive sinking of POC in the North Atlantic. Active carbon flux by the $0-200 \mathrm{~m}$ integrated migrant myctophid biomass, uncorrected for trawl efficiency, ranged from $0.01-0.4 \%$ of sinking POC flux at $150 \mathrm{~m}$ and $0.02-0.95 \%$ at $300 \mathrm{~m}$. If myctophid biomass was corrected for low gear efficiency, flux increased to $0.1-1 \%$ and $0.3-3.5 \%$, respectively, of sinking POC. Lower MAR myctophid biomass resulted in lower active carbon transport compared to myctophids in the Pacific and zooplankton in the North Atlantic estimated in previous studies, but myctophid active transport should still be considered in models of MAR carbon cycling. Due to the role of myctophids as both predators of numerous zooplankton taxa and as prey of higher taxa, information on the feeding ecology and daily consumption of these fishes is necessary to accurately assess their role in the MAR food web and the overall trophic structure of this hydrodynamically and topographically unique ecosystem. 
Myctophid Feeding Ecology and Carbon Transport along the Northern Mid-Atlantic Ridge 


\section{INTRODUCTION}

Fishes of the family Myctophidae are an integral part of the trophodynamics of

oceanic ecosystems around the world, including the North Atlantic Ocean. The diets of myctophids are probably most well known from the eastern and western sides of the North Atlantic Ocean; however, the feeding ecology and role in carbon cycling of myctophids associated with the northern Mid-Atlantic Ridge (MAR), part of the largest topographic feature in the Atlantic Ocean, is completely unknown. The purpose of this thesis is to compare the feeding ecology of, and carbon export by, myctophids at the MAR to myctophids in off-ridge areas of the North Atlantic and other ocean basins.

\section{Myctophid ecology and potential role in carbon export}

Fishes of the family Myctophidae are distributed globally and reside from the surface to depths greater than $1000 \mathrm{~m}$. They are the most numerically abundant mesopelagic fish family in many areas around the world (Frost and McCrone 1979, Balanov and Il'inskii 1992, Beamish et al. 1999, Sutton et al. 2008). Information on the feeding ecology and trophic position of these fishes is critical to the understanding of ecosystem food webs and modeling of large-scale ecological processes in the ocean.

Myctophids generally occupy a tertiary trophic level, feeding primarily on crustacean zooplankton, but they are also known to feed on gelatinous zooplankton, pteropods, and other non-crustacean prey including other fishes (Kinzer 1982, Sameoto 1988, Hopkins et al. 1996, Moku et al. 2000). Hopkins et al. (1996) found that myctophids were the most important consumer in a Gulf of Mexico assemblage consisting of 164 species representing 16 families of midwater fishes, ingesting $31 \%$ of 
the total prey biomass consumed daily by the assemblage. In the eastern Gulf of Mexico, a low-latitude myctophid community consumed $8-16 \%$ of the total copepod daily production and $2 \%$ of the overall zooplankton biomass each night (Hopkins and Gartner 1992). Gorelova (1984) estimated that myctophids may consume $2-31 \%$ (average $10 \%$ ) of the zooplankton standing stock daily in the equatorial Pacific. A wide range of daily consumption has been estimated for myctophids, generally falling within 1-6\% of body weight for adults (Sameoto 1988, Pahkomov et al. 1996, Brodeur and Yamamura 2005). While myctophids are important predators, they are also important prey for higher order predators such as marine mammals, sea birds, and piscivorous fishes (Hopkins et al. 1996, Beamish et al. 1999, Pusineri et al. 2008, Pereira et al. 2011). The diet of stomiid fishes in a Gulf of Mexico assemblage was comprised mainly of fishes (83\% of abundance), of which myctophids represented $42 \%$ (Hopkins et al. 1996). Myctophids have also been identified in the diets of swordfish, albacore tuna, common dolphin, striped dolphin and beaked whales, constituting as much as $50 \%$ of the diet by mass (Pusineri et al. 2008, Pereira et al. 2011). Beamish et al. (1999) postulated that myctophids may constitute up to $90 \%$ of the diets of northern fur seal, Dall's Porpoise, Pacific white-sided dolphin, and northern right whale dolphin in the subarctic Pacific. Additionally, myctophids were a notable component of the diet of many sea birds in this area, including several species of puffins, murres, and kittiwakes (Beamish et al. 1999). Many myctophid species make daily vertical migrations up to the epipelagic zone at night to feed on zooplankton, and migrate to deeper water $(\sim 300-1000 \mathrm{~m})$ during the day where they digest their food. While metabolizing this surface-derived food at depth, myctophids egest large, fast-sinking, carbon-rich fecal pellets, respire carbon dioxide, and 
excrete dissolved organic carbon and dissolved organic and inorganic nitrogen. This "active transport" of organic and inorganic nutrients may be an important component of the biological pump (collectively the vertical export of surface-derived nutrients to depth by vertically migrating zooplankton and fishes, 'passive' sinking of dead phytoplankton aggregates and of fecal pellets, and physical mixing of dissolved organic matter) and subsidizes the metabolic demands of deep-sea organisms in an extremely food-limited environment (Vinogradov 1962, Steinberg et al. 2000, 2008, Hidaka et al. 2001, Wotton and Malmqvist 2001). Hidaka et al. (2001) found the respiratory flux due to vertically migrating micronekton in the western equatorial Pacific (biomass corrected for assumed gear sampling efficiency of $14 \%$ ) to be between $15-30 \mathrm{mg} \mathrm{C} \mathrm{m}^{-2} \mathrm{~d}^{-1}$, which accounted for $28-55 \%$ of the sinking particulate organic carbon (POC) flux, while the gut flux (material consumed near the surface that is egested as fecal pellets at depth) accounted for $2-3 \%$ of POC flux. Respiratory and gut fluxes due to migrant myctophids accounted for approximately $14-26 \%$ and $1-2 \%$, respectively, of the POC flux. In addition, Wilson et al. (2009) reported that carbonate production within the intestines of marine fishes, which is released via excretion, contributes $3-15 \%$ of total oceanic carbonate production. Given that myctophids are the dominant group of vertically migrating fishes and account for the greatest proportion of fish biomass in the epipelagic zone at night (Maynard et al. 1975, Hopkins and Lancraft 1984), myctophids have the potential to export a significant amount of organic and inorganic carbon to the deep sea. 


\section{The Mid-Atlantic Ridge and the MAR-ECO study}

The continental slope regions of the ocean make up a small proportion of the earth's surface area (Garrison 2010). Beyond the narrow continental slope, organisms in the mesopelagic zone rarely encounter land. The high pressures and cold temperatures prevent most mesopelagic organisms from reaching the sea floor, except at seamounts and mid-ocean ridges. Mid-ocean ridges, abrupt, hard-bottomed topographic features that stretch $65,000 \mathrm{~km}$ around the world (Garrison 2010), protrude up into the water column to create relatively shallow, diverse habitat structure in an otherwise structurally homogeneous medium. In the Atlantic Ocean the Mid-Atlantic Ridge (MAR) divides the ocean into nearly equal eastern and western halves. It provides a unique, relatively shallow habitat in the center of the deep Atlantic Ocean and supports a diverse faunal assemblage (Vecchione et al. 2010). The MAR exhibits many unique topographical features including the Charlie-Gibbs Fracture Zone, where deep sub-marine rift valleys run east to west and influence local and regional circulation patterns. Such alterations in circulation patterns may affect the distribution and feeding ecology of deep-sea organisms including those that inhabit the ridge as well as transient (migratory) species (Roden 1987, Bergstad and Godø 2003, Sutton et al. 2008). To date, few ecological studies have focused on the ridge, and hence, little is known about the fauna and ecology of MAR communities.

In 2001, the Census of Marine Life, a 10-year international effort to assess the diversity, distribution, and abundance of marine life, enacted a field project titled Patterns and Processes of the Ecosystem of the Northern Mid-Atlantic (MAR-ECO). This project aimed to describe and understand the patterns of distribution, abundance, and 
trophic relationships of organisms inhabiting and associated with the northern MAR between Iceland and the Azores (Bergstad 2002). Describing the ecological processes that cause variability in these patterns is fundamental to understanding the influence of the MAR on this dynamic ecosystem.

One goal of MAR-ECO was to determine if the trophic structure of the northern MAR ecosystem is similar to that of continental slope regions of the eastern and western Atlantic. The presence of the MAR in the bathypelagic realm, and to a lesser extent in the mesopelagic realm, provides the potential for unique faunal interactions and nutrient availability. Elevated levels of primary productivity and chlorophyll, which are often associated with seamounts, mid-ocean ridges, and frontal zones in oligotrophic regions (Genin and Boehlert 1985, Dower et al. 1992, Muriño et al. 2001), have the potential to support enhanced secondary production and higher order epi- and mesopelagic biomass. Benthopelagic organisms associated with the ridge surface are supported through resuspension of sediment and through predation on pelagic fauna. Non-migrating pelagic fauna become susceptible to predation through advection to the ridge by water currents, while vertically migrating mesopelagic fauna become trapped by the elevated seafloor during their daily migratory descent (Genin and Dower 2007, Porteiro and Sutton 2007). Due to the potential for enhanced nutrient availability and faunal interactions at the MAR, this ecosystem may support a unique community and trophic structure compared to off-ridge waters. 


\section{Pelagic fish community structure of the Mid-Atlantic Ridge}

To investigate the diversity, community structure, and trophic ecology of organisms inhabiting the MAR, MAR-ECO sampled the epi-, meso-, and bathypelagic fauna during a two-part expedition to the ridge during June-July, 2004 aboard the Norwegian vessel R/V G.O. Sars. These cruises were two of many MAR-ECO sampling expeditions to the MAR with the goal of assessing the occurrence, distribution, and ecology of animals and animal communities along the ridge between Iceland and the Azores (Figure 1). Leg 1 of this expedition sampled the pelagic fauna and is the focus of my thesis.

Sampling during leg 1 resulted in the collection of 205 fish species and the classification of the faunal composition within four sections along the MAR and five depth zones (see Methods for description of depth zones). A detailed description of the community structure of the MAR is provided by Sutton et al. (2008). The MAR ecosystem is unique in many ways compared to the surrounding areas of the eastern and western Atlantic. A decrease in faunal abundance and biomass with increasing depth is typically expected for open ocean ecosystems; however, the pelagic MAR fauna exhibited higher than expected abundance and biomass at bathypelagic depths (Sutton et al. 2008). Depth distributions of some MAR fishes were unique in that many species were found over the ridge at depths deeper and shallower than previously recorded, and demersal fish biomass was highest at stations near the summit of the ridge (Bergstad et al. 2008). Community composition of mesopelagic fishes along the ridge was fairly consistent north of the Sub-polar Front, a prominent hydrologic feature crossing the 
MAR between $45-52^{\circ} \mathrm{N}$, which appeared to act as a boundary to the northward distribution of many southern species.

Fishes of the families Myctophidae, Gonostomatidae, Microstomatidae, Stomiidae, and Melamphidae were abundant throughout the ridge with vertically migrating myctophids dominating the 200-750 m depth zone. Forty-five myctophid species were caught along the ridge, however only nine species comprised more than $1 \%$ of the total myctophid abundance by number. In accordance with typical trends of abundance and species richness at high latitudes, the fish assemblage in the three northern ridge sections in the 200-750 $\mathrm{m}$ depth zone comprised only a few abundant species, predominantly myctophids. There was a shift in community composition at the Azorean Zone (AZ) ridge section within the same depth zone. Here, species richness was much higher than farther north and the abundance of each species decreased.

The most abundant fish collected from the ridge during leg 1 of the MAR-ECO cruise was the myctophid Benthosema glaciale. This species made up over half of the abundance by number and one quarter of the biomass in the three northern ridge sections from $0-750 \mathrm{~m}$ but only $6 \%$ and $4 \%$, respectively, in the AZ (Sutton et al. 2008). Benthosema glaciale was also very abundant in deeper waters up to $1500 \mathrm{~m}$ in the Faraday Seamount Zone (FSZ) and AZ due to cooler waters occurring deeper at lower latitudes. While $B$. glaciale exhibited a wide geographic distribution across all four ridge sections, other species, such as Protomyctophum arcticum, appeared to be more limited in their distribution. Protomyctophum arcticum was numerically abundant in the two northern ridge sections with only a few individuals caught at the FSZ and was not captured in the AZ. The distributions of several myctophid species were limited to a 
single ridge section, notably the $\mathrm{AZ}$. In this ridge section, 29 myctophid species made up half of the abundance in the $0-750 \mathrm{~m}$ depth zone and the myctophid Lobianchia dofleini replaced B. glaciale as the numerically dominant species, making up $19 \%$ of the abundance and 7\% of the biomass (Sutton et al. 2008). The myctophid Hygophum hygomii, was unique in that it was a moderately abundant species ( $2.7 \%$ by number) found only at the AZ.

Much is known of the feeding ecology of $B$. glaciale in the North Atlantic; however, active carbon transport by myctophids in this area has not been studied. Very little information exists on the feeding ecology of other species, such as $P$. arcticum and H. hygomii, despite their high abundance. Notwithstanding the ample diet data for some North Atlantic myctophids, comprehensive feeding ecology of myctophids inhabiting the MAR, the largest topographic feature in the Atlantic Ocean, is unknown. Being that myctophids were the most abundant fishes collected from the MAR, and the importance of these fishes as consumers of plankton and prey for many higher order predators, information on the feeding ecology of and carbon transport by these fishes is necessary for an accurate portrayal of food web structure and carbon cycling in the MAR ecosystem.

\section{Objectives and significance of the study}

The main objective of this study was to describe and quantify the feeding ecology of MAR myctophids. A secondary objective was to quantify the contribution of vertically migrating myctophids through the active transport of carbon to the MAR biological pump. The feeding ecology and trophic importance of many species of myctophids from 
around the world have been studied; however, neither the diets of myctophids inhabiting the ecologically distinctive MAR ecosystem nor the potential for carbon transport by vertically migrating MAR myctophids have been investigated. To accomplish the first objective, the diets of three myctophid species- B. glaciale, $P$. arcticum, and $H$. hygomii were investigated by quantifying the prey composition using weight, abundance, and frequency of occurrence indices. To relate the dietary information to the energy requirements and changes in diet with growth of each species, daily consumption was calculated and ontogenetic dietary shifts were explored. Multivariate analyses were used to determine how fish size and different environmental variables influence variance in the diet. To accomplish the second objective, the amount of carbon transported via respiration, excretion, and egestion to mesopelagic depths by vertically migrating MAR myctophids was quantified. This allowed for an estimation of the extent to which MAR myctophids contribute to active carbon transport in comparison to passive sinking of POC, and provide the first estimate of myctophid active transport in the North Atlantic Ocean.

The results from this study provide a comprehensive account of the diet of three abundant mesopelagic species of myctophids from the northern Mid-Atlantic Ridge during the months of June and July. This time of year in the North Atlantic represents an active feeding period for mesopelagic fishes, corresponding with spring phytoplankton blooms and subsequent zooplankton blooms. As a result of the high relative abundance and biomass of myctophids at the MAR, they have the potential to impart heavy predation pressure on zooplankton and to provide an important source of carbon export out of the euphotic zone through metabolism of surface-consumed food at midwater 
depths. Estimates of active transport by mesopelagic fishes are limited, and do not exist for the MAR. These data provide carbon transport estimates for the most abundant vertically migrating, mesopelagic fish family along the MAR that can be used in biogeochemical models that simulate and predict total carbon flux from the euphotic zone. Additionally, due to their intermediate trophic position, information on the diet and feeding ecology of myctophids from the ridge is essential to the successful construction of a MAR ecosystem food web to achieve an understanding of the trophodynamics of the geographically and hydrodynamically unique MAR ecosystem. 


\section{METHODS}

\section{Sampling procedure}

Myctophids were collected during the R/V G.O. Sars research expedition to the Mid-Atlantic Ridge (Iceland to the Azores) during June-July, 2004. Two double-warp, multi-cod end midwater trawls were used to sample the ridge fauna at discrete depth zones. The macrozooplankton trawl has a $6 \times 6 \mathrm{~m}^{2}$ mouth opening, $6 \mathrm{~mm}$ stretched mesh throughout its length, and was equipped with five opening and closing cod ends. The Åkra trawl has a 20-35 m vertical mouth opening, $110 \mathrm{~m}$ door-spread, graded mesh to 22 mm (stretched), and was equipped with three multiple opening and closing cod ends.

Predefined stations along the ridge were sampled discretely within five depth categories: $0-200,200-750,750-1500,1500-2300$, and $>2300 \mathrm{~m}$ in four ridge sections (Figure 1). Average tow duration was 3:43 (hours: minutes) (maximum 6:52, minimum 0:59). Each net was open for an average of 0:53 (maximum 4:46, minimum 0:08). Samples were classified as day (D), dusk (DN), night (N), or dawn (ND) with dusk and dawn samples defined as the start time of the net being one hour before to one hour after sunset and sunrise, respectively (Sutton et al. 2008). Once on board, specimens were sorted and either frozen, or preserved in $10 \%$ buffered formalin. Preserved samples were identified and transferred to $70 \%$ ethanol in the laboratory. For additional detail concerning net sampling aboard the R/V G.O. Sars see Wenneck et al. (2008).

\section{Myctophid selection, dissection, and prey identification}

The three species included in this study, Benthosema glaciale, Protomyctophum arcticum, and Hygophum hygomii were chosen because they fulfilled multiple criteria 
that were needed to obtain a representative sample of the myctophid assemblage in order to investigate trophic ecology and carbon transport. Each species was abundant, occurred primarily in the mesopelagic zone, and was known to conduct diel vertical migration. Benthosema glaciale was very abundant at all of the four ridge sections and was captured in many tows at different depths and times throughout the day. Protomyctophum arcticum was caught in high numbers at the two northern ridge sections at several different depth and time-of-day combinations. Hygophum hygomii was caught only at the southern ridge section, and while the limited geographic distribution restricted the number of possible combinations of depth and time of capture, their numbers still allowed for an adequate description of the diet. The unique geographic distribution of each species allowed for comparisons not only among species, but also across ridge sections and varying environmental regimes.

A subset of specimens from the total catch of the three species was randomly selected for measurement and dissection from as many geographic-location, depth, and time-of-day combinations as were available. A total of $380 \mathrm{fish}$ belonging to three species was included in this study: $265 \mathrm{~B}$. glaciale, $76 \mathrm{P}$. arcticum, and $39 \mathrm{H}$. hygomii. The standard length of each fish was measured to the nearest $0.1 \mathrm{~mm}$ from the tip of the snout to the posterior edge of the caudal peduncle. The stomach and intestines were removed and contents were identified to the lowest possible taxonomic level using a Nikon SMZ 1000 dissecting microscope. Diet descriptions and analyses include prey from stomachs only. Intestinal prey were not included in the diet description due to the tendency for advanced digestion and low taxonomic resolution. Prey types that were observed infrequently were grouped with more common genus or family classifications 
to avoid small sample sizes: Diet indices were calculated for the lowest taxonomic level of grouped prey types that provided adequate sample size (Table 1) as well as broad prey categories at the subclass level (e.g., copepod).

\section{Prey measurements}

The length and width of each prey item was determined to the nearest $0.01 \mathrm{~mm}$ using Image Pro Plus 5.0 software. Cephalosome and urosome length and width measurements were determined for copepods. Since hooks were often all that remained of chaetognaths in the guts, a maximum hook length to body length regression for Pacific Sagitta elegans (Terazaki 1993) was used to estimate body length, and a head width to body length ratio for the same species (Pearre 1980) was used to estimate body width. Total length and width were determined for all remaining prey for which body measurements were possible. For well-digested prey, average body measurements from intact, related taxa were used. Body measurements of prey items were used to calculate body volume using formulae for the most similar geometric shape. Prey volume was then used to determine wet weight (assuming specific gravity $=1.0 \mathrm{~g} \mathrm{cc}^{-1}$ ). Crustacean dry weight was calculated as $20 \%$ of wet weight and carbon as $40 \%$ of dry weight (Silver and Gowing 1991, Steinberg et al. 1998). Conversion factors for other, less abundant prey taxa were utilized as described in Larson (1986) and Steinberg et al. (1998).

\section{General diet description}

The diet of each myctophid species was summarized using three diet indices, percent frequency of occurrence, percent composition by number, and percent dry weight 
after Hyslop (1980). The indices, represented below as $\% I_{j}$, were calculated using a cluster sampling estimator (Buckel et al. 1999, Latour et al. 2008) of the form:

$$
\% I_{j}=\frac{\sum_{i=1}^{n} M_{i k} q_{i k}}{\sum_{i=1}^{n} M_{i k}} \times 100
$$

such that

$$
q_{i k}=\frac{\sum_{k=1}^{n_{k}} w_{i j k}}{\sum_{j=1}^{n_{j}} \sum_{k=1}^{n_{k}} w_{i j k}}
$$

where $n$ is the number of cod ends containing predator $k, M_{i k}$ is the number of predator $k$ collected in cod end $i, n_{j}$ is the number of prey types observed in stomachs of all predator $k$, and $n_{k}$ is the number of predator $k$ stomachs examined. In equation (2), $q_{i k}$ represents the proportion of occurrence, abundance, or weight of each prey type in each cod end. Diet composition indices were calculated as a weighted average of $q_{i k}$ with the abundance of each predator, $M_{i k}$ as the weighting factor. The variance for each diet index was calculated as

$$
\operatorname{var}\left(\% I_{j}\right)=\frac{1}{n \bar{M}^{2}} \frac{\sum_{i=1}^{n} M_{i k}^{2}\left(q_{i k}-I_{j}\right)^{2}}{n-1} \times 100^{2}
$$

after Latour et al. (2008), where $\bar{M}$ is the average number of predator $k$ collected in a cod end. 


\section{Ontogenetic and spatial changes in diet}

The diets of many fishes change as they increase in size due to an increase in gape allowing them to exploit bigger or different prey. To examine the effect of fish size on the diet, individuals of each species were grouped into narrow size classes with the members of each class having a relatively similar diet composition. Benthosema glaciale and $P$. arcticum were grouped into $5 \mathrm{~mm}$ size classes and the proportion of dry weight of each prey type was calculated for each size class. The narrow size classes were grouped into broader categories with similar prey composition based on prey weight using cluster analysis (Euclidean distance, average linkage method) and a scree plot was used to determine the number of clusters.

Canonical correspondence analysis (CCA, ter Braak 1986) is a method which extracts the major gradients in the data that can be accounted for by the measured explanatory variables (McGarigal et al. 2000). For B. glaciale and P. arcticum, CCA was used to investigate the relationship between diet, ridge section (RR, CGFZ, FSZ, AZ; see Figure 1), depth zone $(0-200,200-750,750-1500,1500-2300,>2300 \mathrm{~m})$, and time of day (day, dusk, night, and dawn). Each element of the response matrix for the CCA was the mean percent weight of a given prey type in a particular depth, ridge-section, and timeof-day combination. In CCA, variability is explained by the canonical axes. The canonical axes are linear combinations of the independent explanatory variables which are correlated to the dependent variables, in this case weighted averages of prey. Significance of the explanatory variables was determined using ANOVA, and a biplot was constructed to explore the relationships between the explanatory variables and prey weight: The CCA was performed using $\mathrm{R}$ version 2.12.0. 


\section{Gastric evacuation and daily consumption}

Daily consumption was calculated using an evacuation rate model based on Elliott and Persson (1978). Consumption $\left(C_{d}\right)$ was calculated as

$$
C_{d}=24 h \cdot E \cdot \bar{S}_{k r}
$$

where 24 is the number of hours in a day, $E$ is the evacuation rate, and $\bar{S}_{k r}$ is the average stomach content weight of predator $k$ from ridge section $r$. Evacuation rates at ridgesection specific temperatures were determined using a regression of compiled myctophid

gut evacuation rates and temperatures $\left(E=0.0942 \mathrm{e}^{0.0708 t}\right.$, where $t$ represents temperature) from Pakhomov et al. (1996). Due to the wide latitudinal distribution of the sampling area, myctophids experienced different temperatures at their daytime depths (200-750 m, depth zone 2) between ridge sections. Depth zone 2 is the depth at which myctophids in this study are assumed to reside during the bulk of digestion. Consumption was calculated separately for each ridge section due to evacuation rate dependence on temperature.

\section{Active carbon export by diel vertical migration}

Active carbon export to below $200 \mathrm{~m}$ via respiration of $\mathrm{CO}_{2}$, excretion of dissolved organic carbon (DOC), and egestion of particulate organic carbon (POC) in the form of fecal pellets was determined only for the RR and AZ. Migrator biomass, defined as the difference between night and day integrated myctophid biomass in the $0-200 \mathrm{~m}$ depth interval, could not be determined at the CGFZ and FSZ due to the lack of sufficient diel sampling at these ridge sections. $\mathrm{CO}_{2}$ flux was calculated using the following equation from Dam et al. (1995) 


$$
F=B \cdot R \cdot 12 h
$$

where $F$ is the $\mathrm{CO}_{2}$ flux by migrant myctophids $\left(\mathrm{mg} \mathrm{C} \mathrm{m}^{-2} \mathrm{~d}^{-1}\right), B$ is the biomass of migrant myctophids integrated to $200 \mathrm{~m}\left(\mathrm{mg} \mathrm{DW} \mathrm{m}^{-2}\right), R$ is the weight-specific respiration rate at temperatures experienced by myctophids at their day time residence depths at the $\mathrm{RR}$ or $\mathrm{AZ}\left(6.6\right.$ or $11.8^{\circ} \mathrm{C}$, respectively; calculated using a myctophid oxygen consumption versus temperature regression reported in Donnelly and Torres (1988), which was converted to $\mathrm{CO}_{2}$ respired using carbon and oxygen atomic ratios), and $12 \mathrm{~h}$ is the assumed length of time myctophids spend at depth over a $24-\mathrm{h}$ day. A respiratory quotient of 0.8 was used in the calculation of $R$ (Brett and Groves 1979). DOC excretion information for fishes is lacking, so the relationship of $\mathrm{CO}_{2}$ respiration to DOC excretion in zooplankton (DOC excretion $=31 \% \cdot \mathrm{CO}_{2}$ respiration) reported by Steinberg et al. (2000) was used to estimate DOC excretion in myctophids. POC egestion at depth was calculated using the prey carbon conversions discussed above. It was assumed that $100 \%$ of stomach and intestinal contents of fish caught at the surface would be released below $200 \mathrm{~m}$. The average amount of carbon per unit dry weight of fish biomass was determined for $B$. glaciale and $P$. arcticum and multiplied by the integrated migrator biomass at the RR or AZ and by 12 hours. Myctophid dry weight was determined using a wet weight-standard length regression for each species (Fock and Ehrich 2010) and a wet weight-dry weight ratio (DW/WW $=22.64 \%$ ) based on an average of compiled wet weight-dry weight ratios for many individual myctophid species (Carmo pers. comm.). 


\section{RESULTS}

\section{General diet description}

Benthosema glaciale

Fifty-nine different prey types were identified in 201 positive stomachs $(75 \%$ of all stomachs dissected) to an array of taxonomic levels depending on the extent of digestion. Copepods constituted the bulk of the diet by weight (52\%), were the most frequently occurring prey category ( $93 \%$ of stomachs), and were the most abundant prey ( $90 \%$ of all prey items by number). The copepod Calanus finmarchicus was the predominant copepod in the diet of $B$. glaciale and made up over one quarter of the diet by weight alone. Euphausiids were another major component of the diet, constituting $37 \%$ of the diet by weight and occurring in $21 \%$ of stomachs, but were consumed in low abundance ( $2 \%$ of all prey items by number). Chaetognaths and ostracods constituted $6 \%$ and $3 \%$ of the diet by weight, respectively, while the remaining prey categoriesamphipods, gelatinous prey, fishes, polychaetes, pteropods, digested crustaceans, and unidentified prey, made up $1 \%$ or less of the diet by weight.

\section{Protomyctophum arcticum}

The diet of $P$. arcticum comprised 26 different prey types from 74 positive stomachs ( $97 \%$ of all stomachs dissected) and was made up primarily of copepods $(68 \%)$ and euphausiids $(25 \%)$ by weight. Nearly all $P$. arcticum stomachs contained copepods (93\% of stomachs) with the large copepod Paraeuchaeta norvegica making up the highest proportion of copepod weight (15\%). Ostracods occurred in $37 \%$ of stomachs but constituted only $6 \%$ of the diet by weight and $12 \%$ by number. Digested crustaceans and 
unidentified prey were the only other prey found in the diet of $P$. arcticum and made up less than $1 \%$ of the diet by weight and number.

\section{Hygophum hygomii}

Eighteen different prey types from 28 positive stomachs ( $72 \%$ of all stomachs dissected) were identified in the diet of $H$. hygomii. Euphausiids made up the highest proportion of the diet by weight (53\%) and occurred in $57 \%$ of stomachs; however, they accounted for only $7 \%$ of all prey items by number. Ostracods were eaten frequently and in high numbers, occurring in $80 \%$ of stomachs, making up $37 \%$ of the diet numerically, and constituting one quarter of the diet by weight. Copepods, mainly Pleuromamma sp., Candacia sp., and euchaetid species, were the most frequently consumed prey category ( $84 \%$ of stomachs), and made up half of the diet by number and $15 \%$ by weight. Fishes, amphipods, pteropods, and unidentified prey each made up 5\% or less by weight, although amphipods were found in over half of stomachs.

\section{Ontogenetic and spatial changes in diet}

\section{Benthosema glaciale}

The size range of $B$. glaciale included in this study was $10.7-66.9 \mathrm{~mm}$ standard length (Figure 2). Cluster analysis and a scree plot indicated three clusters of B. glaciale based on diet composition and fish size separated into $5 \mathrm{~mm}$ size classes (Figures $3 \mathrm{~A}$ and B). The clusters of size classes did not parse out into discrete groups of sequential fish sizes (i.e. small, medium, large). Instead, medium and large size classes $(>20 \mathrm{~mm})$ were intermixed within two clusters while the smallest sizes $(10-19.9 \mathrm{~mm})$ clustered together. 
The clusters closely reflect the proportion of euphausiid weight in the diet. Fish in cluster A (Figure 3A) did not contain euphausiids, fish in cluster B possessed a high proportion of euphausiid weight in the diet, and fish in cluster $\mathrm{C}$ contained a low proportion of euphausiid weight in the diet. Due to the lack of evidence of an ontogenetic shift in the diet of B. glaciale beyond the smallest size classes, fish size was not included in subsequent analyses.

Canonical correspondence analysis (CCA) indicated B. glaciale dietary changes in relation to ridge section $(p=0.005)$ and time of day $(p=0.025)$ were significant at $\alpha=$ 0.05 whereas depth $(p=0.25)$ was not significant (Figure 4$)$. The three explanatory variables included in the CCA, depth, ridge section, and time of day, accounted for $30 \%$ of the variability in the diet, collectively. The first and second canonical axes accounted for $34 \%$ and $29 \%$ of the explainable variation, respectively. Ridge section corresponded more closely with the first canonical axis than the second, and accounted for a greater proportion of the explainable variation. The remaining significant explanatory variable, time of day, was more closely correlated to the second axis.

Prey items constituting the bulk of the diet of B. glaciale from the three northern ridge sections were similar to each other but different from prey items in the diet of $B$. glaciale from the AZ (Figure 5A). The diets of B. glaciale from the RR, CGFZ, and FSZ were comprised mainly of euphausiids, $35 \%, 44 \%$, and $65 \%$ by weight, respectively. The copepod Calanus finmarchicus ranked second in the RR and CGFZ, constituting $31 \%$ and $25 \%$ of the diet by weight, respectively, while $P$. norvegica made up $6 \%$ of the diet by weight in the RR and 7\% in the CGFZ. After euphausiids, ostracods and P. norvegica constituted $11 \%$ and $6 \%$ of the diet by weight, respectively, in the FSZ. The diets of $B$. 
glaciale from the AZ differed from those of the three northern ridge sections in that ostracods made up $59 \%$ of the diet by weight. Pleuromamma copepods ( $7 \%$ by weight) were the only other prey to make up greater than $5 \%$ of the diet by weight in B. glaciale from the AZ. Polychaetes were only found in diets of myctophids from the RR, and fish prey and pteropods were only identified in diets from the FSZ. Gelatinous prey was found in the stomachs of fish from the RR, FSZ, and AZ.

The diet of $B$. glaciale collected during the day was comprised mainly of $C$. finmarchicus and euphausiids, $31 \%$ and 29\% by weight, respectively (Figure 5B). Unidentified Calanidae copepods were the primary prey ( $42 \%$ by weight) in the night time diets, while chaetognaths $(67 \%)$ were the predominant prey at dawn. Calanus finmarchicus, pteropods, and fish prey were only identified in fishes collected during the day and polychaetes were only found in dawn samples. It is unlikely that $B$. glaciale did not consume $C$. finmarchicus during the night, rather that poor taxonomic resolution prohibited identification to genus or species level.

\section{Protomyctophum arcticum}

The size distribution of $P$. arcticum was $18-44.5 \mathrm{~mm}$ standard length (Figure 2). The cluster analysis and scree plot (data not shown) indicated there was no ontogenetic change in the diet and, therefore, fish length was not included in the CCA. CCA indicated depth $(\mathrm{p}=0.03)$ to be the only significant factor at $\alpha=0.05$ whereas ridge section $(p=0.46)$ and time of day $(p=0.23)$ were not significant. The three explanatory variables included in the CCA, depth, ridge section, and time of day, accounted for $38 \%$ of the variability in the diet, collectively (Figure 6). The first and second canonical axes 
accounted for $38 \%$ and $32 \%$ of the explainable variation, respectively. Depth zone corresponded more closely with the second canonical axis.

The main difference in $P$. arcticum diet with respect to depth was the high proportion of euphausiids (31\%) in fish collected from depth zone $2(200-750 \mathrm{~m})$ and the absence of euphausiids in fish from depth zone 1 (0-200 m; Figure 7). Paraeuchaeta norvegica was identified in greater proportion in depth zone $2(18 \%)$ than depth zone 1 (7\%). The main components in the diets of fish from depth zone 1 were the copepod Metridia sp. (17\%), ostracods (16\%), C. finmarchicus (13\%), and copepods of the family Aetideidae (12\%).

\section{Hygophum hygomii}

The size distribution of $H$. hygomii was $27.7-56 \mathrm{~mm}$ standard length. There were too few $H$. hygomii at the smallest and largest sizes to allow for cluster analysis of this species. Additionally, since $H$. hygomii was only caught at the AZ and only during the day, CCA was not performed for this species.

\section{Species interaction and the effect on spatial changes in diet}

To investigate the effect of co-occurrence of $B$. glaciale and $P$. arcticum on the feeding ecology of these two species, CCA was performed for two scenarios in which fish species was added as an explanatory variable. In one scenario only cod ends in which both $B$. glaciale and $P$. arcticum were caught were included, and in another scenario all cod ends that caught at least one of the two species were included. When all cod ends that caught at least one of the two species were included in the CCA (Figure 
$8 \mathrm{~A})$, ridge section and fish species were significant $(\mathrm{p}=0.005$ and $\mathrm{p}=0.01$, respectively) at $\alpha=0.05$, while depth zone and time of day were not $(p=0.79$ and $p=0.12$, respectively). The four explanatory variables included in the CCA, depth, ridge section, time of day, and fish species, accounted for $25 \%$ of the variability in the diet, collectively. The first canonical axis accounted for $28 \%$ of the explainable variation while the second axis accounted for $23 \%$. Ridge section corresponded more closely with the first canonical axis and accounted for a greater proportion of the explainable variation, while fish species corresponded more closely to the second axis. Due to the difference in distribution of these two species, it was not surprising that ridge section and fish species were significant.

When only cod ends that contained both species were included in the CCA (Figure 8B), fish species was significant $(p=0.05)$ at $\alpha=0.05$ and time of day approached significance $(\mathrm{p}=0.08)$ which indicated that these two species, when caught together, had significantly different diet compositions, and diets of both species differed slightly between day, night, and dawn. The four explanatory variables accounted for $34 \%$ of the variability in the diet with the first canonical axis accounting for $33 \%$ of the explainable variation and the second axis accounting for $24 \%$. Fish species corresponded more closely to the first canonical axis and time of day corresponded more closely with the second axis.

\section{Gastric evacuation and daily consumption}

Gastric evacuation rates were calculated for each myctophid species using average water temperatures experienced in the $200-750 \mathrm{~m}$ depth zone in each ridge 
section. From the northernmost ridge section to the southernmost, average water temperatures were $6.6{ }^{\circ} \mathrm{C}(\mathrm{RR}), 4.9{ }^{\circ} \mathrm{C}(\mathrm{CGFZ}), 7.6{ }^{\circ} \mathrm{C}(\mathrm{FSZ})$, and $11.8^{\circ} \mathrm{C}(\mathrm{AZ})$, with the decline in temperature at the CGFZ due to the unique physical characteristics of the Subpolar Front, present in this area (Søiland et al. 2008). Evacuation rates increased with increasing temperature and ranged from $0.13-0.22 \mathrm{~h}^{-1}$ (Table 2). The average total weight of prey in the stomachs of B. glaciale was highest at the RR (3.6 $\mu \mathrm{g} \mathrm{DW}$ prey fish $\left.{ }^{-1}\right)$ and for $P$. arcticum at the CGFZ $\left(0.09 \mu \mathrm{g}\right.$ DW prey fish $\left.{ }^{-1}\right)$. Average total weight of prey was lowest for $B$. glaciale in the AZ $\left(0.02 \mu \mathrm{g}\right.$ DW prey fish $\left.{ }^{-1}\right)$ and for $P$. arcticum in the RR $\left(0.03 \mu \mathrm{g} \mathrm{DW}\right.$ prey fish $\left.{ }^{-1}\right)$. Hygophum hygomii was only caught at the $\mathrm{AZ}$ and the average total weight of prey in the stomachs was $0.92 \mu \mathrm{g}$ DW prey fish ${ }^{-1}$. Daily consumption rates per fish were calculated for each species at each ridge section (Table 2), converted to consumption per unit of average myctophid biomass at each ridge section, and were multiplied by the biomass of all myctophid species combined integrated to $2300 \mathrm{~m}$ to provide a range of possible daily consumption estimates of MAR myctophids. Estimated daily consumption of prey inferred for all MAR myctophids ranged from $0.34-42.02 \mu \mathrm{g}$ DW m ${ }^{-2} \mathrm{~d}^{-1}$ at the RR, 1.54-28.37 $\mu \mathrm{g} \mathrm{DW} \mathrm{m} \mathrm{d}^{-1}$ at the CGFZ, $6.83 \mu \mathrm{g} \mathrm{DW} \mathrm{m} \mathrm{m}^{-1}$ at the FSZ, and $0.72-3.35 \mu \mathrm{g} \mathrm{DW} \mathrm{m} \mathrm{m}^{-2} \mathrm{~d}^{-1}$ at the AZ. Daily consumption in proportion to myctophid body weight was always less than $1 \%$ for each species regardless of ridge section.

\section{Active carbon export by diel vertical migration}

Active transport of carbon by diel vertically migrating myctophids was calculated for ridge sections at which both day and night tows were performed in depth zone $1(0-$ 
$200 \mathrm{~m}$ ) and for which night time myctophid biomass was greater than day time myctophid biomass in depth zone 1 . The $\mathrm{RR}$ and $\mathrm{AZ}$ were the only ridge sections that met these criteria. Respiration of $\mathrm{CO}_{2}$ by the $0-200 \mathrm{~m}$ integrated migrant myctophid biomass was $0.01 \mathrm{mg} \mathrm{C} \mathrm{m}^{-2} \mathrm{~d}^{-1}$ at the $\mathrm{RR}$ and $0.27 \mathrm{mg} \mathrm{C} \mathrm{m}^{-2} \mathrm{~d}^{-1}$ at the $\mathrm{AZ}$ (Table 3). Myctophid excretion of DOC (calculated as $31 \%$ of myctophid respiration-see Methods) was $0.003 \mathrm{mg} \mathrm{C} \mathrm{m}^{-2} \mathrm{~d}^{-1}$ at the RR and $0.08 \mathrm{mg} \mathrm{C} \mathrm{m}^{-2} \mathrm{~d}^{-1}$ at the AZ. Egestion of POC was determined for B. glaciale at the RR and AZ and for P. arcticum at the RR. Hygophum hygomii was only collected during the day and therefore migrant biomass and carbon export could not be calculated for this species. Egestion rate of POC by B. glaciale multiplied by the $0-200 \mathrm{~m}$ integrated migrant myctophid biomass resulted in export of $1.61 \times 10^{-6} \mathrm{mg} \mathrm{C} \mathrm{m}^{-2} \mathrm{~d}^{-1}$ at the RR and $1.71 \times 10^{-4} \mathrm{mg} \mathrm{C} \mathrm{m}^{-2} \mathrm{~d}^{-1}$ at the AZ. Substituting egestion rate of POC by $P$. arcticum resulted in export of $7.08 \times 10^{-6} \mathrm{mg} \mathrm{C} \mathrm{m}^{-2} \mathrm{~d}^{-1}$ in the $R R$. Total carbon transport by the migrant myctophid biomass in the RR and AZ was estimated as 0.014 and $0.353 \mathrm{mg} \mathrm{C} \mathrm{m}^{-2} \mathrm{~d}^{-1}$, respectively. 


\section{DISCUSSION}

\section{General diet description}

Benthosema glaciale, $P$. arcticum, and H. hygomii were primarily

zooplanktivorous; however, the zooplankton composition and weight, frequency, and abundance of prey varied among species. The overall diet composition of myctophids from the ridge agrees with previous diet studies of these species (discussed below); however, direct comparison to other studies of prey proportion in diets is not possible due to the difference in sampling estimator used in this study (Equations 1 and 2). When calculating diet indices of fish caught in active sampling gears it is important to consider the sampling design used to collect the fish, as well as the species' ecological characteristics. Fish are known to aggregate in response to environmental gradients, resource availability, and social behavior (Pitcher and Parrish 1993, Pakhomov and Yamamura 2010); therefore, active sampling gear (such as the macrozooplankton and $\AA$ Ara trawls used in this study) are likely to collect groups of fish that are found together in space and time based on a commonality, such as food availability. These groups are likely to consume similar types of prey and in similar quantities and, thus, their diets are likely to be more comparable to each other than to groups collected at different times or locations (Latour pers. comm.). Therefore, in order to characterize the predatory impacts of these fishes at the population level, these groups of fishes, rather than the individual, should be considered the independent sampling unit (Bogstad et al. 1995, Buckel et al. 1999).

The simple random sampling (SRS) estimator is the predominant method used to calculate diet indices of pelagic fishes (Hopkins and Gartner 1992, Moku et al. 2000) and 
assumes that fishes are evenly distributed in the environment and have an equal probability of capture (Cochran 1977). As discussed above, this assumption is often not the case and, hence, the SRS estimator is not an appropriate method to use for calculating diet indices of fishes with aforementioned ecological characteristics. In addition to considering the ecology of the species, the appropriate sampling estimator can be determined mathematically using the intracluster correlation coefficient (ICC, $\rho$ ) which measures the relationship of the variance between groups of fish caught in different cod ends to the variance within a group of fish caught in a single cod end. The parameter $\rho$ can be estimated for each prey type as

$$
\hat{\rho}=\frac{\hat{s}_{b}^{2}}{\hat{s}_{b}^{2}+\hat{s}_{w}^{2}}
$$

where $\hat{s}_{b}^{2}$ is the estimate of variance between groups and $\hat{s}_{w}^{2}$ is the estimate of variance within groups (Steel et al. 1997). As $\hat{s}_{w}^{2}$ decreases towards 0 (signifying stomach contents within cod ends are increasingly similar) $\rho$ approaches 1 . The ICC for several of the most common prey types in the diet for each species ranged from $0.48-0.74$ for $B$. glaciale, $0.42-0.73$ for $P$. arcticum, 0.84-0.98 for H. hygomii, indicating the diets of each species within cod ends tend to be more similar than between cod ends. As a result, a cluster sampling estimator, which treats the groups of fish in each cod end as the independent sampling unit, was used to calculate dietary indices of these three species from the MAR.

Of the three myctophid species included in this study, more is known about the feeding ecology of $B$. glaciale than $P$. arcticum or $H$. hygomii. The diet of B. glaciale from the MAR observed in this study was comprised predominantly of copepods by 
weight, frequency of occurrence, and abundance. Calanus finmarchicus and euphausiids made up the bulk of the diet by weight, with many other copepod taxa, amphipods, ostracods, chaetognaths, pteropods, polychaets, fish, and unidentified gelatinous zooplankton being consumed as well. Although not commonly identified in the diet, myctophids do consume gelatinous prey. Several studies from the Gulf of Mexico reported some larval and adult myctophid species fed on gelatinous prey, with some larvae feeding almost exclusively on gelatinous zooplankton (Hopkins and Gartner 1992, Conley and Hopkins 2004). Hopkins and Gartner (1992) reported gelatinous prey in the diet of Benthosema suborbitale; however, to my knowledge, gelatinous prey has not been reported in the diet of $B$. glaciale. Gelatinous prey was identified in the stomachs of seven $B$. glaciale $>40 \mathrm{~mm}$ from the MAR, equating to less than $1 \%$ of the numerical abundance of prey in the diet. Due to the rapid digestion of gelatinous material, this estimate represents an underestimate of gelatinous zooplankton in the diet of this species. The diet of B. glaciale from the MAR agreed well with many previous studies of this species which reported copepods, predominantly C. finmarchicus, Pleuromamma spp. Metridia spp., and Paraeuchaeta norvegica, to comprise the bulk of the diet while the fish also consumed euphausiids, ostracods, amphipods, pteropods, chaetognaths, and fishes (Gjøsæter 1973, Kinzer 1977, Kawaguchi and Mauchline 1982, Roe and Badcock 1984, Petursdottir et al. 2008).

The diet of $P$. arcticum from the MAR was comprised mainly of copepods, with $P$. norvegica constituting the bulk of the copepod component. Euphausiids and ostracods were the only other identifiable prey in the diet. In a study from the Rockall Trough in the North Atlantic, the diet of $P$. arcticum was also comprised mainly of copepods, 
specifically Pleuromamma spp., as well as other copepods, such as Metridia sp. and Aetideus sp., ostracods, and amphipods (Kawaguchi and Mauchline 1982). In the Davis Strait west of Greenland, C. finmarchicus was the only identifiable prey of $P$. arcticum (Sameoto 1989). The diet of $H$. hygomii from the MAR, mainly euphausiids and copepods, also agreed well with previous studies; however, fish prey was surprisingly abundant, constituting $5 \%$ of the diet by abundance at the MAR. In previous studies at Great Meteor Seamount and in the Gulf of Mexico, H. hygomii fed on copepods, amphipods, chaetognaths, euphausiids, mysids, ostracods, pteropods and unidentified gelatinous prey (Hopkins and Gartner 1992, Pusch et al. 2004).

Diets of these three species likely reflect their different geographic distributions. Benthosema glaciale occurred at all four ridge sections but was considerably less abundant at the $\mathrm{AZ}, P$. arcticum occurred at the three northern ridge sections, primarily the RR and CGFZ, and H. hygomii was collected only from the AZ. Sutton et al. (2008) identified a shift in the midwater fish assemblage composition from the three northern ridge sections to the $\mathrm{AZ}$, and a similar pattern was also observed in the distribution of some copepod taxa. Gaard et al. (2008) found that the Sub-Polar Front (SPF) appeared to act as a boundary to the horizontal distribution of several copepod species. Most copepod genera that dominated north of the front were also present to the south but the species were often different. The front appeared to restrict the northward distribution of southern copepod genera more so than the reverse, as 14 genera were restricted to the south of the SPF whereas only 4 were restricted to the north (Gaard et al. 2008). Some of these patterns in copepod distribution were evident in the diet of the MAR myctophids in this study, and are discussed below. 


\section{Ontogenetic and spatial changes in diet}

Once general diet characteristics are known, it is useful to investigate what impact certain biotic and abiotic variables have on the diet. Fish size is one factor that can influence the composition of the diet. As a fish grows, different prey sizes and taxa become available for exploitation and noting the changes in the diet is important in understanding the ontogenetic changes in the ecology of the species. To avoid bias associated with assigning fish to broad size bins with breaks at which dietary changes are expected to occur, and then comparing the diets among those specified size bins, $B$. glaciale and $P$. arcticum were, instead, assigned to small, $5 \mathrm{~mm}$ size bins, ensuring fish within those bins had a relatively similar diet, and cluster analysis was used to determine at what sizes dietary changes occurred. Again, due to a difference in methodology direct comparison of ontogenetic dietary changes cannot be made with other studies but general diet trends with size can be compared.

Cluster analysis indicated there were no ontogenetic changes in the diet of $B$. glaciale beyond the smallest size classes, although three clusters were resolved (Figures 3A and $\mathrm{B})$. The formation of these clusters was driven mainly by the weight of euphausiids in the diet of fish within the $5 \mathrm{~mm}$ size classes. Cluster A contained the smallest $B$. glaciale size classes included in this study, 10-19.9 mm. These fish did not consume euphausiids but fed heavily on Pleuromamma copepods, ostracods, amphipods and unidentified calanoid copepods. Fish $>20 \mathrm{~mm}$ consumed euphausiids and were clustered into two groups, those with a moderate proportion (cluster C) and those with a high proportion (cluster B) of euphausiids (by weight) in the diet. Kinzer (1977) found only $B$. glaciale $>30 \mathrm{~mm}$ consumed euphausiids and amphipods, whereas diets of 20-24.9 
$\mathrm{mm}$ B. glaciale in this study comprised $30 \%$ of the euphausiids by weight consumed by all size classes, and the smallest $B$. glaciale size class $(10-14.9 \mathrm{~mm})$ consumed the greatest proportion of amphipods. Size classes between 30-54.9 mm consumed the highest proportion of $C$. finmarchicus copepods, suggesting that as B. glaciale increases in size and larger prey items can be consumed, they do not exclude small prey items from the diet (Dalpadado and Gjøsæter 1988, Sameoto 1988). Conversely, Kawaguchi and Mauchline (1982) found the largest B. glaciale (36.1-62.5 mm) to exclude the smallest copepods and substitute large prey such as euphausiids and fish. Similar trends of exclusion were identified in the diets of other myctophid species as well (Hopkins et al. 1996, Pakhomov et al. 1996).

Cluster analysis indicated there was no ontogenetic change in diet of $P$. arcticum sampled from the MAR, and only one cluster was identified. The main difference in the diet amongst the different size classes was the high proportion of euphausiids ( $77 \%$ by weight) in the largest size class $40-44.9 \mathrm{~mm}$. Euphausiids were present in all other size classes except the smallest (20-24.9 mm) but in much smaller proportions. Larger $P$. arcticum also ate more of the large copepod $P$. norvegica. Ostracods were eaten in fairly even proportions across all size classes while smaller $P$. arcticum tended to feed more heavily on Metridia spp., C. finmarchicus and other calanoid copepods. To my knowledge, aside from larval Protopmyctophum thompsoni (Sassa and Kawaguchi 2005), detailed data of Protomyctophum spp. diet by size was previously unknown.

Sufficient sample size to perform a cluster analysis was not available for $H$. hygomii but a general comparison of the diets within several size classes follows. The diet across the different size classes (25-29.9, 35-39.9, 40-44.9, 45-49.9, and 50-59.9 
$\mathrm{mm}$ ) was very similar with most prey types occurring in each size class. Each of the size classes consumed primarily euphausiids with the proportion of euphausiid weight ranging from $52-82 \%$ of all prey weight in the size class. All $H$. hygomii size classes also contained ostracods and the copepods Pleuromamma spp., Oncaea spp., and Candacia spp. Fish prey only occurred in the $45-49.9 \mathrm{~mm}$ size class and pteropods occurred only in the 40-44.9 mm size class. Pusch et al. (2004) reported the numerical diet composition of H. hygomii in $10 \mathrm{~mm}$ size classes from $20-70 \mathrm{~mm}$ standard length. Copepods were the most abundant prey in the diet of all size classes except the largest, of which amphipods were the most abundant. Ostracods, pteropods, and euphausiids were consumed in low numbers in all size classes. Data from this study agreed with Pusch et al. (2004) in that copepods were eaten in high numbers in each size class; however, ostracods were eaten in equal or greater amounts compared to copepods at small and large sizes and amphipods were eaten in low abundance.

In addition to fish size, spatial and temporal factors also influence diet composition. Several different water masses are present along the MAR within the study site (Søiland et al. 2008). Water masses have different sources and characteristics such as water temperature which can influence the distribution of zooplankton and fishes both latitudinally and vertically and which, in turn, influences the available prey. Most myctophids and zooplankton are diel vertical migrators to varying degrees, remaining in isolumes throughout the water column that minimize the risk of predation but maximize the opportunity for feeding (Pearre 2003, Cohen and Forward 2009, Ringelberg 2010, Staby and Aksnes 201.1). Some plankton undergo extensive migrations of hundreds of meters, while others may only travel short distances (Angel 1989, Anderson and Sardou 
1992). Depending on the depth and time of day at which myctophids feed, each species could be feeding on a different prey field which would result in unique dietary composition. Thus, time of day, depth, and latitude (represented by ridge section) were included in a CCA to investigate the influence of these explanatory variables on the variability in the diet.

The CCA indicated a significant change in the diet of $B$. glaciale with respect to ridge section and time of day. As previously mentioned, the zooplankton community composition south of the SPF differed from ridge sections north of the front for many species and the shift in $B$. glaciale diet in the AZ reflects this change (Figure 5A). The abundance of $C$. finmarchicus, the numerically dominant calanoid copepod north of the SPF, declined by two orders of magnitude to the south of the front. This decrease in $C$. finmarchicus abundance is reflected in the diet of $B$. glaciale as it was not identified in the diet south of the SPF. The dominant components of B. glaciale diet in the three northern ridge sections, $C$. finmarchicus and euphausiids, were replaced by ostracods in the AZ. The separation of the AZ and corresponding prey from the other ridge sections in the CCA biplot reflect these trends (Figure 4).

There were several interesting differences between the diets of $B$. glaciale caught during the day, night, and dawn (there was only one dusk sample and, thus, it was not included). The most surprising difference was the absence of $C$. finmarchicus from night and dawn samples while constituting $31 \%$ of the diet by weight of $B$. glaciale during the day. The absence of $C$. finmarchicus from the diet at night and dawn could be due to mismatch in vertical distribution of predator and prey; although, Gaard et al. (2008) reported $C$. finmarchicus was present from 0-2500 $\mathrm{m}$ at the MAR during the same 
sampling period. Alternatively, the absence of $C$. finmarchicus could be an artifact of poor taxonomic resolution and conservative identification as unidentified Calanidae copepods made up $42 \%$ of night diets by weight. Chaetognaths made up a much greater proportion of the diet by weight of $B$. glaciale during dawn, constituting $67 \%$ of the diet by weight, versus $4 \%$ in day samples and $<1 \%$ in night samples. However, the high proportion of chaetognath weight in dawn samples could be anomalous as there were only two (large) chaetognaths identified in these stomachs with the remaining prey consisting of small copepods and ostracods. Other differences in diet with regard to time of day include the presence of pteropods and fish only in day samples and polychaetes only in dawn samples, although these items made up a very small proportion of the weight and occurred in low abundance. The proportion of weight of most remaining prey items were fairly consistent in day and night samples, while less than half of prey types were identified in dawn samples.

Of the explanatory variables included in the $P$. arcticum $\mathrm{CCA}$, the only significant variable was depth. Protomyctophum arcticum was collected primarily from depth zones 1 and 2 and these were the only depths included in the CCA. Vertical migration can influence the variety and quantity of prey available, however, vertical distribution and diel vertical migration data for adult $P$. arcticum are lacking, making it difficult to interpret how depth affects the diets of fish from different depths zones. Nafpaktitis (1977) and Hulley (1984) report depths of $P$. arcticum maximum abundance during the day and night in the North Atlantic to be $350 \mathrm{~m}$ (range of 250-850 m) and $250 \mathrm{~m}$ (range of 90-325 m), respectively, suggesting $P$. arcticum may exhibit a weak vertical migration. During the day, $P$. arcticum from the MAR exhibited typical patterns of abundance 
corresponding to diel vertical migration, with abundance in depth zone 2 much higher than in depth zone 1; however, night time abundance was nearly equal in depth zones 1 and 2 which could be due to a sizeable proportion of $P$. arcticum abundance remaining at depth and not performing diel vertical migration (Watanabe et al. 1999). Alternatively, the limited night time sampling at the two northern ridge sections may not have been adequate to capture the true migratory pattern of this species, as the typical pattern of higher abundance at depth in the day, and surface waters at night, of $P$. arcticum was recorded during a subsequent MAR-ECO expedition to the CGFZ in 2009 (Cook et al. in press).

The main difference in $P$. arcticum diet between depth zones 1 and 2 was the presence of euphausiids only in stomachs collected during the day in depth zone 2, constituting $31 \%$ by weight of the diets from this depth. The observed difference in euphausiids with depth may be due to euphausiid diel vertical migration. However, abundances of euphausiids were much higher in depth zone 2 than in depth zone 1 during both day and night (unpublished data). It is unlikely that fish size is the underlying factor dictating euphausiid consumption as there was only a $4 \mathrm{~mm}$ increase in average $P$. arcticum size from depth zone $1(28.4 \mathrm{~mm} \mathrm{SL})$ to depth zone $2(32.1 \mathrm{~mm} \mathrm{SL})$ and the size range of $P$. arcticum that consumed euphausiids encompassed the average length of fish in each depth zone (28-44.5 mm SL). Other characteristics of $P$. arcticum diet from depth zones 1 and 2 include aetideid copepods, C. finmarchicus, Metridia sp., and ostracods, all of which are known vertical migrators (Al-Mutairi and Landry 2001, Irigoien et al. 2004), constituting a considerably greater proportion of the diet by weight 
in depth zone 1 , while $P$. norvegica made up a greater proportion in depth zone 2 . Other prey were generally consumed in similar proportions at both depths.

In an attempt to determine if co-occurring species consume similar prey, $\mathrm{CCA}$ was performed including diet data of both $B$. glaciale and $P$. arcticum. Both species exhibited different horizontal distributions along the MAR and, consequently, were exposed to different prey fields, especially $B$. glaciale south of the SPF. To remove the influence of contrasting distributions, only $B$. glaciale and $P$. arcticum that were caught together in the same cod end were included. Fish species was a significant explanatory variable which indicates the diets of these two species, when caught together, are significantly different. In many cod ends where both species were caught, prey items identified in the stomachs of one species were typically absent or consumed in much lower proportion by the other species (Table 4). Time of day also approached significance when only co-occurring samples were included, driven mainly by rare prey and prey types that made up a high proportion of the weight which were eaten at only one time of day. Although niche overlap is not calculated here due to a lack of consensus as to which measure is most accurate and least biased (Smith and Zaret 1982), these differences in diet may suggest that some degree of resource partitioning could exist to reduce competition. It must be kept in mind, as always, that the differences in the diet could partially be due to poor taxonomic resolution.

\section{Daily Consumption}

The maximum daily consumption as a percentage of dry body weight for myctophids in this study was $0.01 \%$, below minimum values from previous studies. 
Although a variety of methods have been used and direct comparisons are not possible, the consensus is that myctophids generally consume $<1-6 \%$ of dry body weight per day, with most estimates closer to 1\% (see table 6.2 in Brodeur and Yamamura (2005) and sources therein). Average water temperature in depth zone 2 was lowest at the CGFZ and highest at the $\mathrm{AZ}$ and, thus, calculated evacuation rates followed the same pattern since evacuation rate is typically positively correlated with temperature to a maximum (Table 2) (Elliott and Persson 1978 and sources therein). Daily consumption by B. glaciale was highest at the RR and decreased to the AZ, while daily consumption by $P$. arcticum increased from the RR to the CGFZ. Hygophum hygomii was only collected in the AZ and consumed a moderate amount compared to B. glaciale. Daily consumption estimates for MAR myctophids presented here are likely to be an underestimate as a result of the sampling design employed on the G.O. Sars cruise. Shallow depth zones were sampled first and, thus, myctophids collected in depth zones 1 and 2 would continue digesting for many hours after capture while the deeper depths were sampled. This prolonged digestion would result in an underestimation of prey abundance in stomachs and, consequently, underestimation of prey weight as a percentage of fish body weight. Additionally, estimation of daily consumption of diel vertically migrating subarctic myctophid species, which assumes only surface feeding at night, can be underestimated due to active feeding during the day at depth. If day time feeding is not accounted for, it could lead to an underestimate of the true daily consumption (Brodeur and Yamamura 2005). Although day time feeding was observed in both B. glaciale and P. arcticum, the number of feeding periods over a 24 hour cycle could not be discerned from stomach fullness data. 
In order to accurately estimate the amount of prey consumed by the MAR myctophid assemblage, an accurate estimate of myctophid biomass is required. Midwater trawls have been the predominant tool used to estimate fish biomass in the past but acoustic measurements are becoming increasingly more common and are shedding light on inaccuracies of midwater trawls. Kaartvedt et al. (2012) estimated the sampling efficiency of a large ( $\sim 400 \mathrm{~m}^{2}$ mouth area) Harstad trawl using acoustics to verify the catch of B. glaciale. They found B. glaciale was capable of avoiding the large trawl to such an extent that the sampling efficiency was $14 \%$. A similarly low sampling efficiency was determined by Koslow et al. (1997) for a medium-sized IYGPT trawl (105 $\mathrm{m}^{2}$ mouth area). In the present study, myctophid biomass was estimated using the small (36 $\mathrm{m}^{2}$ mouth area) macrozooplankton trawl since the fixed mouth area of this trawl allowed for a more accurate calculation of volume of water filtered than the large ( $\sim 660$ $\mathrm{m}^{2}$ mouth area) Åkra trawl. Heino et al. (2011) determined the Åkra trawl to be more efficient at catching fish than the macrozooplankton trawl with a relative catchability of 2.3. Because $B$. glaciale appears to be capable of avoiding even large midwater trawls, the sampling efficiency of the macrozooplanton trawl could potentially be even lower than $14 \%$ for large, stronger swimming myctophids, while the smaller mesh of the macrozooplankton trawl would retain small fish better than the Åkra trawl.

The daily consumption by the MAR myctophid biomass reported in Table 2 is based on the myctophid biomass collected with the macrozooplankton trawl. If the $14 \%$ efficiency estimation reported by Koslow et al. (1997) and Kaartvedt et al. (2012) is applied here, the daily consumption of the MAR integrated myctophid biomass feeding in the 0-200 m depth zone at night ranges from 0.1-18 ug DW m $\mathrm{m}^{-2}$ in the RR, 14 ug DW 
$\mathrm{m}^{-2} \mathrm{~d}^{-1}$ in the FSZ, and 4-18 ug DW m $\mathrm{m}^{-2} \mathrm{~d}^{-1}$ in the $\mathrm{AZ}$ (myctophids were not caught at night in depth zone 1 at the CGFZ). Zooplankton biomass was not estimated at the MAR, so integrated zooplankton biomass estimates were used from Gallienne et al. (2001) in the area of $47^{\circ} \mathrm{N} 20^{\circ} \mathrm{W}$ in the North Atlantic during July, 1996 for the RR (reported carbon values converted to dry weight using the conversion carbon $=40 \%$ • DW), and 0-200 m integrated values from the Bermuda Atlantic Time-series Study (BATS) station in the Sargasso Sea during June and July, 2004 (http://bats.bios.edu/, Steinberg et al. 2012) for the AZ to estimate the portion of the zooplankton biomass removed daily. Gallienne et al. (2001) reported żooplankton biomass in the North Atlantic was $763.5 \mathrm{mg} \mathrm{DW} \mathrm{m}^{-2}$ (vertically integrated to $200 \mathrm{~m}$ ), and average nighttime zooplankton biomass at the BATS station was $735 \mathrm{mg} \mathrm{DW} \mathrm{m}^{-2}$. Applying the B. glaciale consumption rate to the $\mathrm{RR}$ and the $H$. hygomii consumption rate to the $\mathrm{AZ}$ integrated migrant myctophid biomass adjusted for gear efficiency resulted in the removal of $<1 \%$ of zooplankton biomass at each ridge section every night. Estimated removal rates at the MAR were lower than daily zooplankton removal rates by myctophids reported in previous studies: $1-4 \%$ of zooplankton standing stock in the upper $150 \mathrm{~m}$ in the western North Pacific (Watanabe et al. 2002), 2\% in the upper $200 \mathrm{~m}$ in the Gulf of Mexico (Hopkins and Gartner 1992), and 5-20\% in the upper $300 \mathrm{~m}$ in the Southern Ocean (Pakhomov et al. 1999).

\section{Active carbon export by diel vertical migration}

Diel vertically migrating zooplankton contribute to the vertical export of carbon from the euphotic zone through respiration, excretion, and egestion (Longhurst et al. 
1990, Schnetzer and Steinberg 2002), which could be an important source of carbon for non-migrating mesopelagic zooplankton, and for bacteria, which are ultimately reliant on surface-derived production (Steinberg et al. 2008). Diel vertically migrating fishes also have the potential to contribute to the active transport of carbon; however, only one study has quantified the contribution of mesopelagic fishes to the active transport of carbon to meso- and bathypelagic depths (Hidaka et al. 2001). Myctophids are the most abundant vertically migrating mesopelagic fishes in many areas, including the MAR, thus it is important to include active carbon transport for these mesopelagic fishes as potential contributors to the biological pump.

These estimates of active carbon transport out of the euphotic zone can be compared to passive POC flux measured by sediment traps to explore the relative importance of active vs. passive transport as components of the biological pump (Steinberg et al. 2000, Hidaka et al. 2001). Passive POC flux data from the MAR is currently unavailable and, hence, direct comparison to myctophid carbon export cannot be made for the MAR. There are, however, numerous measurements of sediment trap POC flux in the North Atlantic, mainly during the time of the North Atlantic spring bloom. Using results from several studies in the North Atlantic during April and May (Bender et al. 1992, Buesseler et al. 1992, Ducklow et al. 1993, Harrison et al. 1993, Martin et al. 1993), a range of passive POC flux values measured with sediment traps were compiled to compare to active transport by vertically migrating MAR myctophids. Sampling during the G.O. Sars cruise was performed during a post bloom period (Gaard et al. 2008) and, therefore, POC sinking rates would be lower than those during the spring bloom. The present study estimated the active transport of carbon out of the surface 200 
$\mathrm{m}$, but the compiled POC flux data were measured at $150 \mathrm{~m}$ and $300 \mathrm{~m}$, so comparisons are made with flux data at both depths.

The migrant myctophid biomass was $5.2 \mathrm{mg} \mathrm{C} \mathrm{m}^{-2}$ (integrated to $200 \mathrm{~m}$ ) in the $\mathrm{RR}$ and $40 \mathrm{mg} \mathrm{C} \mathrm{m}^{-2}$ in the $\mathrm{AZ}$, and active transport of $\mathrm{CO}_{2}$, DOC, and POC during summer by MAR myctophids was $\leq 1 \%$ of passively sinking POC in the North Atlantic at $150 \mathrm{~m}$ and $300 \mathrm{~m}$ (Table 3). Another study investigating active carbon export by myctophids in the western equatorial North Pacific Ocean found myctophid biomass (uncorrected for net sampling efficiency) was $249-462 \mathrm{mg} \mathrm{C} \mathrm{m}^{-2}$ from 0-160 m, and active transport through respiration and egestion was $1.2-2.2 \mathrm{mg} \mathrm{C} \mathrm{m}^{-2} \mathrm{~d}^{-1}$, equivalent to 2.0-3.7\% of passively sinking POC (Hidaka et al. 2001, stations 15 and 16). Hidaka et al. (2001) adopted the $14 \%$ sampling efficiency estimated by Koslow et al. (1997) which dramatically increased their migrating myctophid biomass estimate (1778-3303 $\mathrm{mg} \mathrm{C} \mathrm{m}^{-2}$ ) and, subsequently, carbon export (8.4-15.4 $\mathrm{mg} \mathrm{C} \mathrm{m}^{-2} \mathrm{~d}^{-1}, 14.3-26.4 \%$ of passively sinking POC). If the same sampling efficiency is applied to MAR myctophid biomass, active transport increases to $0.1 \mathrm{mg} \mathrm{C} \mathrm{m}^{-2} \mathrm{~d}^{-1}$ in the $\mathrm{RR}$ and $2.5 \mathrm{mg} \mathrm{C} \mathrm{m}^{-2} \mathrm{~d}^{-1}$ in the $\mathrm{AZ}$, equivalent to $0.1-1.0 \%$ of sinking POC at $150 \mathrm{~m}$ and $0.3-3.5 \%$ at $300 \mathrm{~m}$. The very high migrant myctophid biomass in the Pacific is the reason for the considerably higher active carbon transport estimated there compared to the MAR. MAR myctophid active transport is also lower than the long-term (1994-2011) annual average zooplankton active transport in the subtropical North Atlantic measured at the BATS station. There, zooplankton transported $4.1 \mathrm{mg} \mathrm{C} \mathrm{m}^{-2} \mathrm{~d}^{-1}$ via respiration, excretion, and egestion at depth, which was, on average, $15 \%$ of sinking POC flux (Steinberg et al. 2012). 
Due to the rapid decline of sinking POC with increasing depth, the carbon transported by vertically migrating myctophids-of which some species migrate to $1000 \mathrm{~m}$ or more, becomes increasingly important at greater depths. As a rough comparison, Honjo and Manganini (1993) report passive POC flux at $1000 \mathrm{~m}$ in the North Atlantic during April of $4.1 \mathrm{mg} \mathrm{C} \mathrm{m}^{-2} \mathrm{~d}^{-1}$. Using corrected MAR myctophid biomass, the myctophid carbon export measured in this study would be equivalent to $61 \%$ of sinking POC at $1000 \mathrm{~m}$. A few factors would decrease the amount of carbon transported to this depth, however. A smaller proportion of the migrating myctophid biomass resides at $1000 \mathrm{~m}$ during the day, and greater migration distance means increased time for digestion to occur resulting in a smaller proportion of POC actively exported out of the euphotic zone being released at $1000 \mathrm{~m}$. Nevertheless, the high proportion of carbon exported by myctophids in relation to POC flux at greater depths reaffirms the importance of myctophids in the biological pump and sequestration of carbon in the deep sea, and suggests that myctophid active transport should be considered in carbon cycling models. 


\section{CONCLUSION}

Overall, the diet of the three species of myctophids from the MAR analyzed in the present study agreed well with previous investigations of these species in off-ridge areas of the North Atlantic Ocean. However, the most abundant myctophid, B. glaciale, possessed some unique dietary and ecological characteristics not observed in this species elsewhere, such as consumption of gelatinous prey, and consumption of euphausiids and amphipods earlier in the fish's life history (i.e., at smaller fish sizes), which may suggest that the distinctive MAR ecosystem supports a unique food-web structure. It must be kept in mind, however, that this study provides information for only a limited period of time during the year and the conclusions cannot be extrapolated beyond the summer. Additional sampling during different times of year is necessary to determine if the differences observed in this study are characteristic of annual patterns at the MAR. Despite the limited temporal scale of this study, the resulting myctophid feeding data represents a necessary first step for the construction of a MAR food web for comparing the trophic structure of the MAR to continental slope regions of the eastern and western Atlantic.

Hidaka et al. (2001) provided an estimate of active carbon transport by myctophids in the Pacific Ocean and the current study provides the first estimate for Atlantic myctophids. Carbon transport by myctophids at the MAR during summer was low compared to sinking POC flux measured in the upper mesopelagic zone during the spring bloom, but may potentially account for a much greater proportion of exported carbon at lower mesopelagic depths. Additional spatial and temporal sampling and information on sampling efficiency of an array of trawl types are needed to develop more 
robust estimates of active carbon transport by myctophids and other migrating fishes. Despite the high abundance of myctophids throughout the world's oceans, the present study is only the second to quantify the active transport of carbon to mesopelagic depths by these vertically migrating fishes. The inclusion of migrating fishes will lead to a more comprehensive view of the biological pump, which has implications for fueling deep-sea food webs, the microbial loop, and for sequestration of atmospheric $\mathrm{CO}_{2}$. 


\section{LITERATURE CITED}

Al-Mutairi H, Landry MR (2001) Active export of carbon and nitrogen at Station ALOHA by diel migrant zooplankton. Deep-Sea Res Part II 48:2083-2103

Anderson V, Sardou J (1992) The diel migrations and vertical distributions of zooplankton and micronekton in the Northwestern Mediterranean Sea. 1. Euphausiids, mysids, decapods and fishes. J Plankton Res 14(8):1129-1154

Angel MV (1989) Does mesopelagic biology affect the vertical flux? In: Berger WH, Smetacek VS, Wefer G (eds) Productivity in the ocean: present and past. WileyInterscience, New York, NY

Baird RC, Hopkins TL, Wilson DF (1975) Diet and feeding chronology of Diaphus taaningi (Myctophidae) in the Cariaco Trench. Copeia 1975(2):356-365

Balanov AA, Il'inskii EN (1992) Species composition and biomass of mesopelagic fishes in the Sea of Okhotsk and the Bering Sea. J Ichthyol 32:85-93

Beamish RJ, Leask KD, Ivanov OA, Balanov AA, Orlov AM, Sinclair B (1999) The ecology, distribution, and abundance of midwater fishes of the Subarctic Pacific gyres. Prog Oceanogr 43:399-442

Bender M, Ducklow H, Kiddon J, Marra J, Martin J (1992) The carbon balance during the 1989 spring bloom in the North Atlantic Ocean, $47^{\circ} \mathrm{N}, 20^{\circ} \mathrm{W}$. Deep-Sea Res $39(10): 1707-1725$

Bergstad OA (2002) MAR-ECO- "Patterns and processes of the ecosystems of the Northern Mid-Atlantic"; an international project under the Census of Marine Life programme. International Research: Biological Studies 11(1):12-14

Bergstad OA, Godø OR (2003) The pilot project "Patterns and processes of the ecosystems of the northern Mid-Atlantic": aims, strategy and status. Oceanol Acta 25:219-226

Bergstad OA, Menezes G, Høines ÅS (2008) Demersal fish on a mid-ocean ridge: Distribution patterns and structuring factors. Deep-Sea Res Part II 55:185-202

Bogstad B, Pennington M, Vølstad JH (1995) Cost-efficient survey designs for estimating food consumption by fish. Fish Res 23:37-46

Brett JR, Groves TDD (1979) Physiological energetics. In: Hoar WS, Randall DJ, Brett JR (eds) Fish physiology, Vol 8. Academic Press, New York, NY

Brodeur R, Yamamura O (eds) (2005) Micronekton of the North Pacific. PISCES Sci Rep No. 30. North Pacific Marine Science Organization, Sidney, BC 
Buckel JA, Conover DO, Steinberg ND, McKown KA (1999) Impact of ago-0 bluefish (Pomatomus saltatrix) predation on age-0 fishes in the Hudson River estuary: evidence for density-dependent loss of juvenile striped bass (Morone saxatilis). Can J Fish Aquat Sci 56:275-287

Buesseler KO, Bacon MP, Cochran JK, Livingston HD (1992) Carbon and nitrogen export during the JGOFS North Atlantic Bloom Experiment estimated from 234Th:238U disequilibria. Deep-Sea Res 39(7-8):1115-1137

Cochran WG (1977) Sampling Techniques, 3rd Edition. John Wiley \& Sons, New York, NY

Cohen JH, Forward Jr. RB (2009) Zooplankton diel vertical migration- a review of proximate control. Oceanogr Mar Biol 47:77-110

Conley WJ, Hopkins TL (2004) Feeding ecology of lanternfish (Pices: Myctophidae) larvae: Prey preferences as a reflection of morphology. Bull Mar Sci 75(3):361379

Cook AB, Sutton TT, Galbraith JK, Vecchione M, Deep-pelagic (0-3000 m) fish assemblage structure over the Mid-Atlantic Ridge in the area of the Charlie-Gibbs Fracture Zone. Deep-Sea Res Part II, http://dx.doi.org/10.1016/j.dsr2.2012.09.003

Dalpadado P, Gjøsæter J (1988) Feeding ecology of the lanternfish Benthosema pterotum from the Indian Ocean. Mar Biol 99:555-567

Dam HG, Roman MR, Youngbluth MJ (1995) Downward export of respiratory carbon and dissolved inorganic nitrogen of diel-migrant mesozooplankton and the JGOFS Bermuda time-series station. Deep-Sea Res Part I 42(7):1187-1197

Donnelly J, Torres JJ (1988) Oxygen consumption of midwater fishes and crustaceans from the eastern Gulf of Mexico. Mar Biol 97:483-494

Dower J, Freeland H, Juniper K (1992) A strong biological response to oceanic flow past Cobb seamount. Deep-Sea Res 39(7-8):1139-1145

Ducklow HW, Kirchman DL, Quinby HL, Carlson CA, Dam HG (1993) Stocks and dynamics of bacterioplankton carbon during the spring bloom in the eastern North Atlantic Ocean. Deep-Sea Res Part II 40(1-2):245-263

Elliott JM, Persson L (1978) The estimation of daily rates of food consumption for fish. J Anim Ecol 47(3):977-991 
Fock HO, Ehrich S (2010) Deep-sea pelagic nekton biomass estimates in the North Atlantic: horizontal and vertical resolution of revised data from 1982 and 1983. J Appl Ichthyol 26:85-101

Frost BW, McCrone LE (1979) Vertical distribution, diel vertical migration, and abundance of some mesopelagic fishes in the eastern subarctic Pacific Ocean in summer. Fish Bull 76(4):751-770

Gaard E, Gislason A, Falkenhaug T, Søiland H, Musaeva E, Vereshchaka A, Vinogradov G (2008) Horizontal and vertical copepod distribution and abundance on the MidAtlantic Ridge in June 2004. Deep-Sea Res Part II 55:59-71

Gallienne CP, Robins DB, Woodd-Walker RS (2001) Abundance, distribution and size structure of zooplankton along a $20^{\circ}$ west meridional transect of the northeast Atlantic Ocean in July. Deep-Sea Res Part II, 48:925-949

Garrison T (2010) Oceanography: an invitation to marine science. Brooks/Cole, Belmont, CA

Genin A, Boehlert GW (1985) Dynamics of temperature and chlorophyll structures above a seamount: an oceanic experiment. J Mar Res 43:907-924

Genin A, Dower JF (2007) Seamount plankton dynamics. In: Pitcher TJ, Morato T, Hart PJB, Clark MR, Haggan N, Santos RS (eds) Seamounts: ecology, fisheries, and conservation. Wiley-Blackwell, Oxford

Gjøsæter J (1973) The food of the myctophid fish, Benthosema glaciale (Reinhardt), from western Norway. Sarsia 52:53-58

Gorelova TA (1984) A quantitative assessment of consumption of zooplankton by epipelagic lanternfishes (family Myctophidae) in the equatorial Pacific Ocean. J Ichthyol 23:106-113

Harrison WG, Head EJH, Horne EPW, Irwin B, Li WKW, Longhurst AR, Paranjape MA, Platt T (1993) The western North Atlantic Bloom Experiment. Deep-Sea Res Part II 40(1-2):279-305

Heino M, Porteiro FM, Sutton TT, Falkenhaug T, Godø OR, Piatkowski U (2011) Catchability of pelagic trawls for sampling deep-living nekton in the mid-North Atlantic. ICES J Mar Sci 68(2)377-389

Hidaka K, Kawaguchi K, Murakami M, Takahashi M (2001) Downward transport of organic carbon by diel migratory micronekton in the western equatorial Pacific: its quantitative and qualitative importance. Deep-Sea Res Part I 48:1923-1939 
Honjo S, Manganini SJ (1993) Annual biogenic particle fluxes to the interior of the North Atlantic Ocean; studied at $34^{\circ} \mathrm{N} 21^{\circ} \mathrm{W}$ and $48^{\circ} \mathrm{N} 21^{\circ} \mathrm{W}$. Deep-Sea Res Part I 40(1-2):587-607

Hopkins TL, Baird RC (1977) Aspects of the feeding ecology of oceanic midwater fishes. In: Andersen NR, Zahuranec BJ (eds) Oceanic sound scattering prediction. Plenum Press, New York, NY

Hopkins TL, Lancraft TM (1984) The composition and standing stock of mesopelagic micronekton at $27^{\circ} \mathrm{N} 86^{\circ} \mathrm{W}$ in the eastern Gulf of Mexico. Contrib Mar Sci $27: 143-158$

Hopkins TL, Gartner Jr. JV (1992) Resource-partitioning and predation impact of a lowlatitude myctophid community. Mar Biol 114:185-197

Hopkins TL, Sutton TT, Lancraft TM (1996) The trophic structure and predation impact of a low latitude midwater fish assemblage. Prog Oceanogr 38:205-239

Hulley PA (1984) Myctophidae. In: Whitehead PJP, Bauchot ML, Hureau JC, Nielsen J, Tortonese E (eds) Fishes of the north-eastern Atlantic and the Mediterranean, Vol 1. UNESCO, Paris

Hyslop EJ (1980) Stomach contents analysis-a review of methods and their application. J Fish Biol 17:411-429

Irigoien X, Conway DVP, Harris RP (2004) Flexible diel vertical migration behaviour of zooplankton in the Irish Sea. Mar Ecol Prog Ser 267:85-97

Kaartvedt S, Staby A, Aksnes DL (2012) Efficient trawl avoidance by mesopelagic fishes causes large underestimation of their biomass. Mar Ecol Prog Ser 456:1-6

Kawaguchi K, Mauchline J (1982) Biology of myctophid fishes (family Myctophidae) in the Rockall Trough, northeastern Atlantic Ocean. Biol Oceanogr 1(4):337-373

Kinzer J (1977) Observations on feeding habits of the mesopelagic fish Benthosema glaciale (Myctophidae) off NW Africa. In: Andersen NR, Zahuranec BJ (eds) Oceanic sound scattering prediction. Plenum Press, New York, NY

Kinzer J (1982) The food of four myctophid fish species off northwest Africa. Rapp P-v Réun Cons int Explor Mer 180:385-390

Koslow JA, Kloser RJ, Williams A (1997) Pelagic biomass and community structure over the mid-continental slope off southeastern Australia based upon acoustic and midwater trawl sampling. Mar Ecol Prog Ser 146:21-35 
Larson RJ (1986) Water content, organic content, and carbon and nitrogen composition of medusae from the northeast Pacific. J Exp Mar Biol Ecol 99:107-120

Latour RJ, Gartland J, Bonzek CF, Johnson RA (2008) The trophic dynamics of summer flounder (Paralichthys dentatus) in Chesapeake Bay. Fish Bull 106:47-57

Longhurst AR, Harrison WG (1989) The biological pump: profiles of plankton production and consumption in the upper ocean. Prog Oceanogr 22:47-123

Longhurst AR, Bedo AW, Harrison WG, Head EJH, Sameoto DD (1990) Vertical flux of respiratory carbon by oceanic diel migrant biota. Deep-Sea Res 37(4):685-694

Martin JH, Fitzwater SE, Gordon RM, Hunter CN, Tanner SJ (1993) Iron, primary production and carbon-nitrogen flux studies during the JGOFS North Atlantic Bloom Experiment. Deep-Sea Res Part II 40(1-2):115-134

Maynard SD, Riggs FV, Walters JF (1975) Mesopelagic micronekton in Hawaiian waters: faunal composition, standing stock, and diel vertical migration. Fish Bull 73(4):726-736

McGarigal K, Cushman S, Stafford S (2000) Multivariate statistics for wildlife and ecology research. Springer, New York, NY

Michaels AF, Bates NR, Buesseler KO, Carlson CA, Knap AH (1994) Carbon-cycle imbalances in the Sargasso Sea. Nature 372:537-540

Moku M, Kawaguchi K, Watanabe H, Ohno A (2000) Feeding habits of three dominant myctophid fishes, Diaphus theta, Stenobrachius leucopsarus and S. nannochir, in the subarctic and transitional waters of the western North Pacific. Mar Ecol Prog Ser 207:129-140

Muriño B, Fernádez E, Serret P, Harbour D, Sinha B, Pingree R (2001) Variability and seasonality of physical and biological fields at the Great Meteor Tablemount (subtropical NE Atlantic). Oceanol Acta 24(2):167-185

Nafpaktitis BG, Backus RH, Craddock JE, Haedrich RL, Robison BH, Karnella C (1977) Family Myctophidae. In: Gibbs Jr. RH (ed) Fishes of the western North Atlantic. Sears Foundation for Marine Research, Memoir, No. 1, Part 7. Yale University

Pakhomov, EA, Perissinotto R, McQuaid CD (1996) Prey composition and daily rations of myctophid fishes in the Southern Ocean. Mar Ecol Prog Ser 134:1-14

Pakhomov EA, Perissinotto R, Froneman PW (1999) Predation impact of carnivorous macrozooplankton and micronekton in the Atlantic sector of the Southern Ocean. J Mar Syst 19:47-64 
Pakhomov E, Yamamura O (2010) Report of the advisory panel on micronekton sampling inter-calibration experiment. PICES Scientific Report No. 38. North Pacific Marine Science Organization (PICES), Sidney, BC

Pearre Jr. S (1980) Feeding by Chaetognatha: the relation of prey size to predator size in several species. Mar Ecol Prog Ser 3:125-134

Pearre Jr. S (2003) Eat and run? The hunger/satiation hypothesis in vertical migration: history, evidence and consequences. Biol Rev 78:1-79

Pereira JN, Neves VC, Prieto R, Silva MA, Cascão I, Oliveira C, Cruz MJ, Medeiros JV, Barreiros JP, Porteiro FM, Clarke D (2011) Diet of mid-Atlantic Sowerby's beaked whales Mesoplondon bidens. Deep-Sea Res Part I 58:1084-1090

Petursdottir H, Gislason A, Falk-Petersen S, Hop H, Svavarsson J (2008) Trophic interactions of the pelagic ecosystem over the Reykjanes Ridge as evaluated by fatty acid and stable isotope analyses. Deep-Sea Res Part II 55:89-93

Pitcher TJ and Parrish JK (1993) Functions of shoaling behavior in teleosts. In: Pitcher TJ (ed) Behaviour of teleost fishes. Chapman and Hall, London

Porteiro FM, Sutton T (2007) Midwater fish assemblages and seamounts. In: Pitcher TJ, Morato T, Hart PJB, Clark MR, Haggan N, Santos RS (eds) Seamounts: ecology, fisheries and conservation. Blackwell, Oxford

Pusch C, Schnack-Schiel S, Mizdalski E, von Westernhagen H (2004) Feeding ecology of three myctophid species at the Great Meteor Seamount (North-east Atlantic). Arch Fish Mar Res 51(1-3):251-271

Pusineri C, Chancollon O, Ringelstein J, Ridoux V (2008) Feeding niche segregation among the Northeast Atlantic community of oceanic top predators. Mar Ecol Prog Ser 361:21-34

Ringelberg J (2010) Diel vertical migration of zooplankton in lakes and oceans: causal explanations and adaptive significances, vol 1 . Springer, Dordrecht

Roden GI (1987) Effect of seamounts and seamount chains on ocean circulation and thermohaline structure. In: Keating BH, Fryer P, Batiza R, Boehlert GW (eds) Seamounts, islands, and atolls. Geophysical Monograph 43, American Geophysical Union, Washington, DC

Roe HSJ, Badcock J (1984) The diel migrations and distributions within a mesopelagic community in the North East Atlantic. 5. Vertical migrations and feeding of fish. Prog Oceanogr 13:389-424 
Sassa C, Kawaguchi K (2005) Larval feeding habits of Diaphus theta, Protomyctophum thompsoni, and Tarletonbeania taylori (Pisces: Myctophidae) in the transition region of the western North Pacific. Mar Ecol Prog Ser 298:261-276

Sameoto DD (1988) Feeding of lantern fish Benthosema glaciale off the Nova Scotia Shelf. Mar Ecol Prog Ser 44:113-129

Sameoto DD (1989) Feeding ecology of the lantern fish Benthosema glaciale in a subarctic region. Polar Biol 9:169-178

Schnetzer A, Steinberg DK (2002) Active transport of particulate organic carbon and nitrogen by vertically migrating zooplankton in the Sargasso Sea. Mar Ecol Prog Ser 234:71-84

Silver MW, Gowing MM (1991) The "particle" flux: origins and biological components. Prog Oceanogr 26:75-113

Smith EP, Zaret TM (1982) Bias in estimating niche overlap. Ecology 63(5):1248-1253

Søiland H, Budgell WP, Knutsen Ø (2008) The physical oceanographic conditions along the Mid-Atlantic Ridge north of the Azores in June-July 2004. Deep-Sea Res Part II 55:29-44

Staby A, Aksnes DL (2011) Follow the light- diurnal and seasonal variations in vertical distribution of the mesopelagic fish Maurolicus muelleri. Mar Ecol Prog Ser 422:265-273

Steel RGD, Torrie JH, Dickey DA (1997) Principles and procedures of statistics: a biometrical approach. McGraw-Hill, New York, NY

Steinberg DK, Pilskaln CH, Silver MW (1998) Contribution of zooplankton associated with detritus to sediment trap 'swimmer' carbon in Monterey Bay, California, USA. Mar Ecol Prog Ser 164:157-166

Steinberg DK, Carlson CA, Bates NR, Goldthwait SA, Madin LP, Michaels AF (2000) Zooplankton vertical migration and the active transport of dissolved organic and inorganic carbon in the Sargasso Sea. Deep-Sea Res Part I 47:137-158

Steinberg DK, Van Mooy BAS, Buesseler KO, Boyd PW, Kobari T, Karl DM (2008) Bacterial vs. zooplankton control of sinking particle flux in the ocean's twilight zone. Limnol Oceanogr 53(4):1327-1338

Steinberg DK, Lomas MW, Cope JS (2012) Long-term increase in mesozooplankton biomass in the Sargasso Sea: linkage to climate and implications for food web dynamics and biogeochemical cycling. Global Biogeochem Cycles 26:1-16 
Sutton TT, Porteiro FM, Heino M, Byrkjedal I, Langhelle G, Anderson CIH, Horne J, Søiland H, Falkenhaug T, Godø OR, Bergstad OA (2008) Vertical structure, biomass and topographic association of deep-pelagic fishes in relation to a midocean ridge system. Deep-Sea Res Part II 55:161-184

ter Braak CJF (1986) Canonical correspondence analysis: a new eigenvector technique for multivariate direct gradient analysis. Ecology 67:1167-1179

Terazaki M (1993) Deep-sea adaptation of the epipelagic chaetognath Sagitta elegans in the Japan Sea. Mar Ecol Prog Ser 98:79-88

Vecchione M, Bergstad OA, Byrkjedal I, Falkenhaug T, Gebruk AV, Godø OR, Gislason A, Heino M, Høines ÅS, Menezes GMM, Piatkowski U, Priede IG, Skov H, Søiland H, Sutton T, de Lange Wenneck T (2010) Biodiversity Patterns and Processes on the Mid-Atlantic Ridge. In: McIntyre AD (ed) Life in the World's Oceans: Diversity, Distribution, and Abundance. Wiley-Blackwell, Oxford, UK

Vinogradov ME (1962) Feeding of the deep-sea zooplankton. Rapports et ProcèsVerbaux des Réunions du Conseil International pour l'Exploration de la Mer 153(18):114-120

Watanabe H, Moku M, Kawaguchi K, Ishimaru K, Ohno A (1999) Diel vertical migration of myctophid fishes (Family Myctophidae) in the transitional waters of the western North Pacific. Fish Oceanogr 8(2):115-127

Watanabe H, Kawaguchi K, Hayashi A (2002) Feeding habits of juvenile surfacemigratory myctophid fishes (family Myctophidae) in the Kuroshio region of the western North Pacific. Mar Ecol Prog Ser 236:263-272

Wenneck T de Lange, Falkenhaug T, Bergstad OA (2008) Strategies, methods, and technologies adopted on the R.V. G.O. Sars MAR-ECO expedition to the MidAtlantic Ridge in 2004. Deep-Sea Res Part II 55:6-28

Wilson RW, Millero FJ, Taylor JR, Walsh PJ, Christensen V, Jennings S, Grosell M (2009) Contribution of fish to the marine inorganic carbon cycle. Science $323: 359-362$

Wotton RS, Malmqvist B (2001) Feces in aquatic ecosystems. BioScience 51(7):537-544 


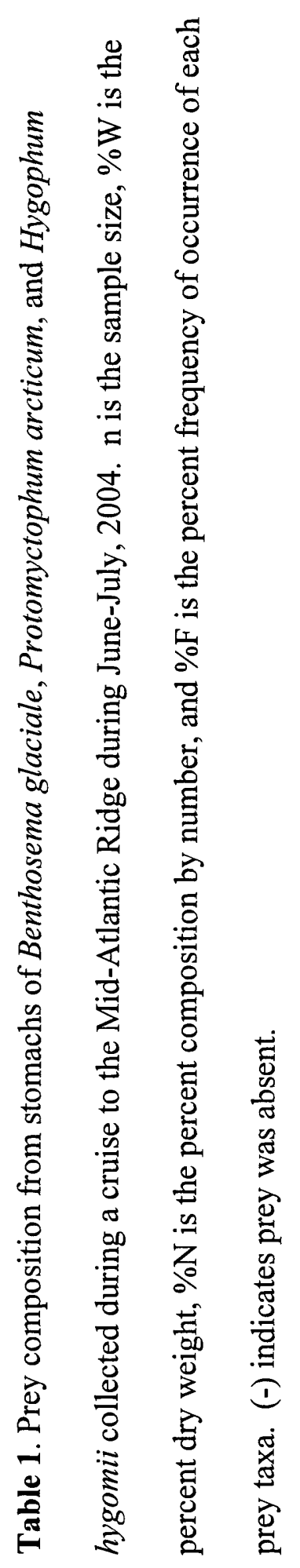




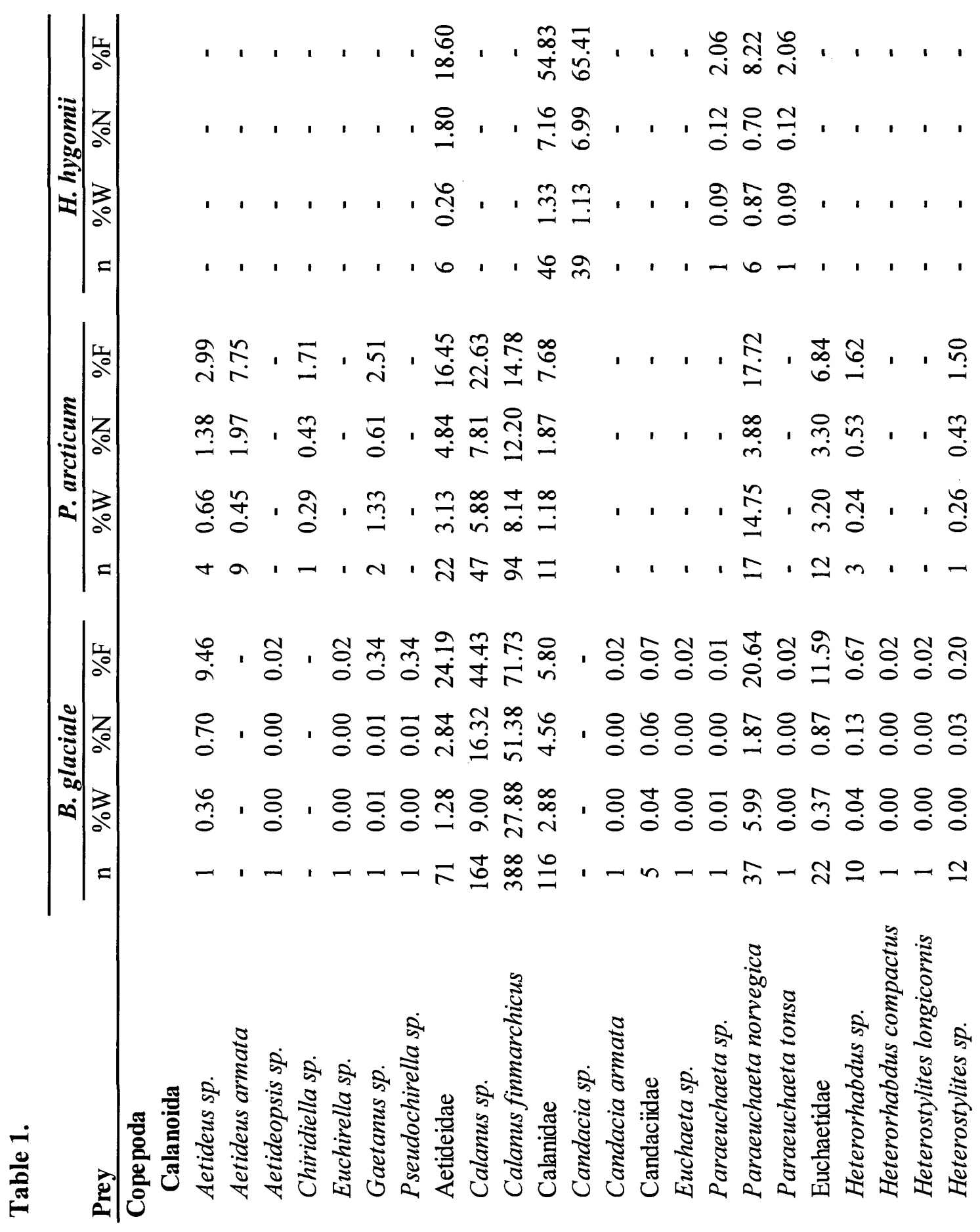




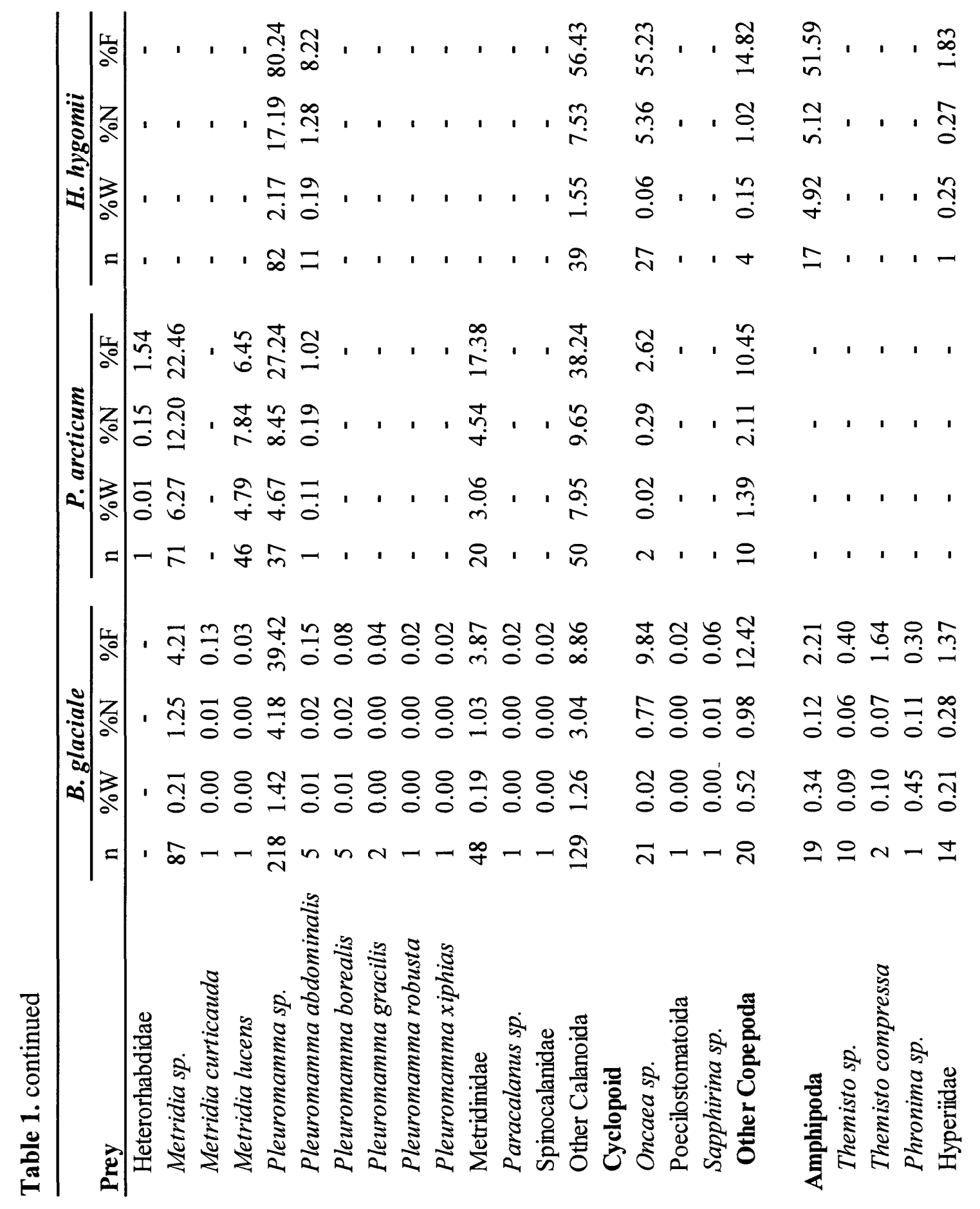




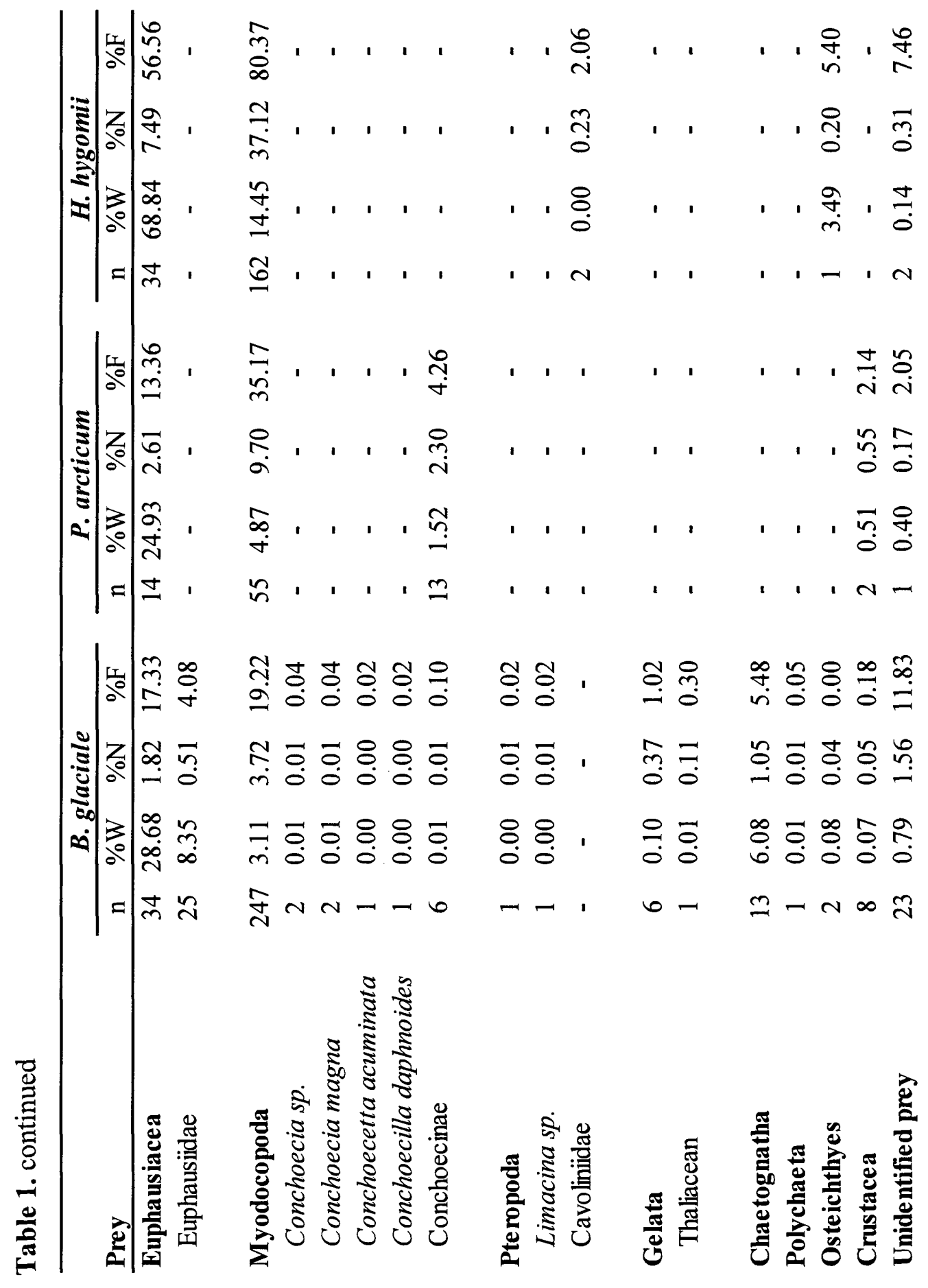


Table 2. Evacuation rates and average daily consumption $\left(\mu \mathrm{g} \mathrm{DW} \mathrm{d} \mathrm{d}^{-1}\right)$ per fish at each ridge section (RR, Reykjanes Ridge; CGFZ, Charlie-Gibbs Fracture Zone; FSZ, Faraday Seamount Zone; AZ, Azorean Zone) for Benthosema glaciale, Protomyctophum arcticum, and Hygophum hygomii. Values in parentheses are potential daily consumption $\left(\mu \mathrm{g} \mathrm{DW} \mathrm{m} \mathrm{m}^{-2} \mathrm{~d}^{-1}\right)$ by the biomass of all myctophid species at each ridge section integrated 0-2300 $\mathrm{m}$ using the average consumption per unit fish biomass of each of the three species. (-) indicates species was not collected from ridge section.

\begin{tabular}{cccccc}
\hline & & & \multicolumn{3}{c}{ Daily Consumption } \\
\cline { 3 - 6 } Ridge Section & $\mathrm{T}^{\circ} \mathrm{C}$ & Rate $\left.\mathrm{h}^{-1}\right)$ & B. glaciale & P. arcticum & H. hygomii \\
\hline RR & 6.6 & 0.150 & $12.99(42.02)$ & $0.11(0.34)$ & - \\
CGFZ & 4.9 & 0.133 & $6.99(28.37)$ & $0.28(1.54)$ & - \\
FSZ & 7.6 & 0.161 & $1.74(6.83)$ & - & - \\
AZ & 11.8 & 0.217 & $0.10(0.72)$ & - & $4.79(3.35)$ \\
\hline
\end{tabular}


Table 3. Active transport of carbon $\left(\mathrm{mg} \mathrm{C} \mathrm{m}^{-2} \mathrm{~d}^{-1}\right)$ by diel migrating myctophids from the Reykjanes Ridge (RR) and Azorean Zone (AZ). Active transport of $\mathrm{CO}_{2}$ and dissolved organic carbon (DOC) is for the $0-200 \mathrm{~m}$ integrated biomass of all myctophid species combined. Active transport of particulate organic carbon (POC) is the average carbon content of prey from night time 0-200 m Benthosema glaciale diets multiplied by the 0$200 \mathrm{~m}$ integrated biomass of all myctophid species combined. Total myctophid carbon export across 0-200 $\mathrm{m}$ is compared to average POC flux in the North Atlantic Ocean from different locations and depths* during April and May.

\begin{tabular}{ccccccc}
\hline Ridge Section & $\mathrm{CO}_{2}$ & DOC & POC & Total & \multicolumn{2}{c}{ \% of Average POC Flux* } \\
\hline & & & & & $150 \mathrm{~m}$ & $300 \mathrm{~m}$ \\
\hline $\mathrm{RR}$ & 0.011 & 0.003 & $1.61 \times 10^{-6}$ & 0.014 & $0.01-0.02$ & $0.02-0.04$ \\
$\mathrm{AZ}$ & 0.270 & 0.084 & $1.71 \times 10^{-4}$ & 0.353 & $0.14-0.41$ & $0.49-0.95$ \\
\hline
\end{tabular}

* POC flux ranged from $86-259 \mathrm{mg} \mathrm{C} \mathrm{m}^{-2} \mathrm{~d}^{-1}$ at $150 \mathrm{~m}$ and $37-72 \mathrm{mg} \mathrm{C} \mathrm{m}^{-2} \mathrm{~d}^{-1}$ at $300 \mathrm{~m}$ (Bender et al. 1992, Buesseler et al. 1992, Ducklow et al. 1993, Harrison et al. 1993, Martin et al. 1993) 


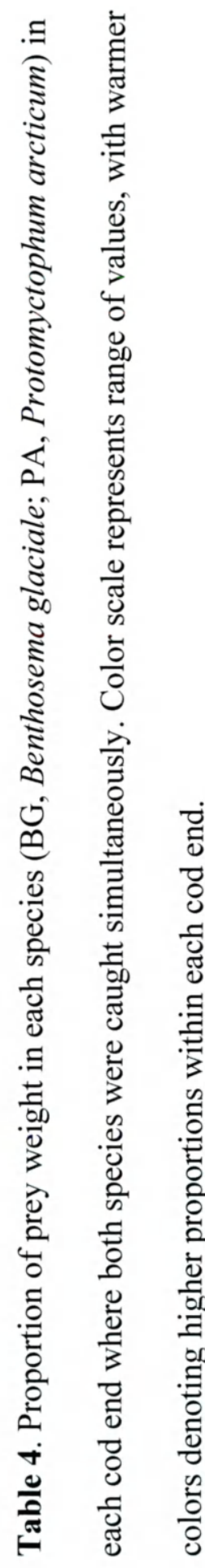

\begin{tabular}{|c|c|c|c|c|c|c|c|c|c|c|}
\hline 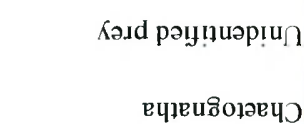 & $\begin{array}{l}\text { ¿ } \\
8 \\
0 \\
8\end{array}$ & $\begin{array}{ll}0 & 0 \\
0 & 0\end{array}$ & $\begin{array}{ll}0 & 0 \\
0 & 0\end{array}$ & $\begin{array}{ll}0 & 0 \\
0 & 0\end{array}$ & $\begin{array}{l}\text { ปै } \\
\text { ป } \\
0\end{array}$ & 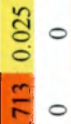 & $\mid \begin{array}{ll}5 & 0 \\
0 & 0 \\
0 & 0 \\
0 & 0\end{array}$ & {$\left[\begin{array}{ll}\tilde{8} & 0 \\
0 & 0 \\
0 & 0\end{array}\right.$} & $\mid \begin{array}{ll}0 & \text { ల్ } \\
0 & 0 \\
0 & 0\end{array}$ & $\begin{array}{l}0 \\
0 \\
0\end{array}$ \\
\hline 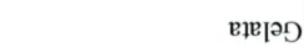 & ले 。 & $\circ 0$ & 00 & $\circ 0$ & 00 & 00 & $\begin{array}{ll}0 & 0\end{array} \mid$ & 00 & 00 & 00 \\
\hline 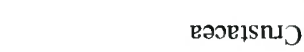 & 00 & ○ & $\circ \stackrel{\Xi}{\delta}$ & 00 & 00 & 00 & 00 & 100 & 00 & 00 \\
\hline epodoəopo $\hat{K}_{\mathrm{W}}$ & के ० & $\circ 0$ & $\circ$ ठ & 00 & $\circ \frac{1}{0}$ & 00 & - & 긍 응 & ० ฐ & ○ ู่ \\
\hline 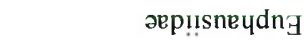 & 00 & $\circ 0$ & 00 & $\circ 0$ & 00 & 00 & 00 & I & है. & 00 \\
\hline вəวе!sneydn马 & 00 & 00 & ○ & $\circ 0$ & 00 & 00 & $\infty$ & $\cong$ ป & 政 & 20 \\
\hline 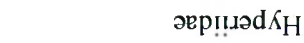 & 00 & 00 & $\circ 0$ & $\circ 0$ & 00 & $\circ 0$ & 00 & $\frac{9}{2} 0$ & E. & $\circ 0$ \\
\hline epod!̣dury & Iㅇ & 0 o & $\circ 0$ & $\circ 0$ & $\circ 0$ & 00 & 00 & ర్ & 0 & $\circ 0$ \\
\hline вpodədoว دәчџО & & 00 & $\circ$ \& & ० ฮั & 00 & $\circ 0$ & $\circ$ ह & $0 \div$ & 00 & $\circ 0$ \\
\hline pמoupip & ㅇ $\infty$ & ? & . & 。 & లి జ & $\infty \cong$ & 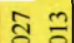 & \& & \% & $\stackrel{\sim}{\sim}$ \\
\hline (p? & 00 & o) & 0 & 0 & 00 & 00 & 00 & 00 & 00 & 00 \\
\hline әвр!рqвчлоләрН & & 0 o. & 00 & $\circ 0$ & 00 & 00 & 00 & 00 & 0 & ० ถิ \\
\hline 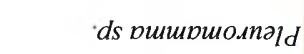 & 궁 & ○ రి & 00 & - \&े & ชู & ○ & $\overline{0}$ & ชี ซิ & 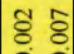 & $8 \frac{\mathrm{m}}{0}$ \\
\hline 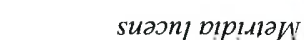 & 0 & $0 \%$ & $\circ \circ$ & 00 & 00 & 00 & 00 & ० \& & ०น & 00 \\
\hline ds pipı-1la $\mathrm{W}^{\top}$ & ० क्ल & 00 & $\circ \stackrel{\frac{m}{0}}{0}$ & $\circ$ ర & ० సે & స。 & $\circ 8$ & $\frac{1}{0}$ & प्ठ & ० \\
\hline 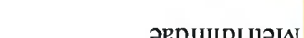 & ๓ి & 00 & 0 & 00 & กิ & - के & - ol rarrat & ธิ & ธั ะ & $ㅇ$ \\
\hline & & & & & & & & & 00 & \\
\hline 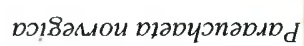 & ले。 & ० & ते० & 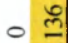 & กี & 。 $\frac{\infty}{6}$ & 00 & $\Xi \infty$ & 。요 & \\
\hline & & & & & & & & & & \\
\hline әврџювчәп & $\circ 0$ & 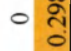 & $\circ:$ & $\circ 0$ & $\circ 0$ & 00 & $\overline{0} 0$ & 8 & $\begin{array}{ll}0 & 0\end{array}$ & 00 \\
\hline 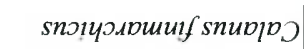 & $\circ 0$ & 00 & 00 & $\circ$ 음 & - & 00 & \&ి ڤ & ম্ণ & 80 & 00 \\
\hline$d s$ snupjp & 00 & $\bar{n} 0$ & స్ర ర్లి & 0 & สิ แ & है 。 & ○ & 过。 & 웅 $\frac{n}{0}$ & કे E \\
\hline & & & & & 2, $\infty$ & 8 & & & 18 & \\
\hline әер!иерЈว & $\circ 0$ & ก & ஸี० & -0 & $\frac{1}{0}$ & 0 : & 0 & ${ }_{0}^{\circ} 0$ & 0 & 0 \\
\hline$d s$ snәриџу & ० ชิ & $\circ$ 응 & 00 & 00 & 00 & 00 & ○ & 00 & 00 & 00 \\
\hline әерцәрџюу & 00 & ॰ ชี & $\frac{0}{2}$ & 00 & जू 。 & ల్రం & ○ \&ి| & 8 으 & $\hat{8}$ f & 0 . \\
\hline & & & & & & & & & & \\
\hline səḷodS & 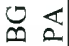 & 0 & U্口 & $\begin{array}{ll}0 & \nwarrow\end{array}$ & 0 & $\mathbb{D}_{0} \leq$ & 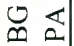 & 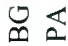 & $\begin{array}{ll}0 & \mathbb{0} \\
0\end{array}$ & 0 \\
\hline pนə роэ & $\widetilde{\S}$ & ฮิ & $\stackrel{\infty}{\widetilde{\sigma}}$ & స్రి & ఠิ & กี & ฮิ & $\underset{\Xi}{\Xi}$ & $\hat{s}$ & ڤ્ \\
\hline uo!̣อs әశిp!ళ & $\frac{\alpha}{\simeq}$ & $\stackrel{\frac{\alpha}{\alpha}}{\alpha}$ & $\frac{2}{x}$ & $\frac{\alpha}{\simeq}$ & $\stackrel{\frac{\alpha}{x}}{\simeq}$ & $\frac{a}{x}$ & $\stackrel{2}{\alpha}$ & 诘 & 売 & 0 \\
\hline
\end{tabular}




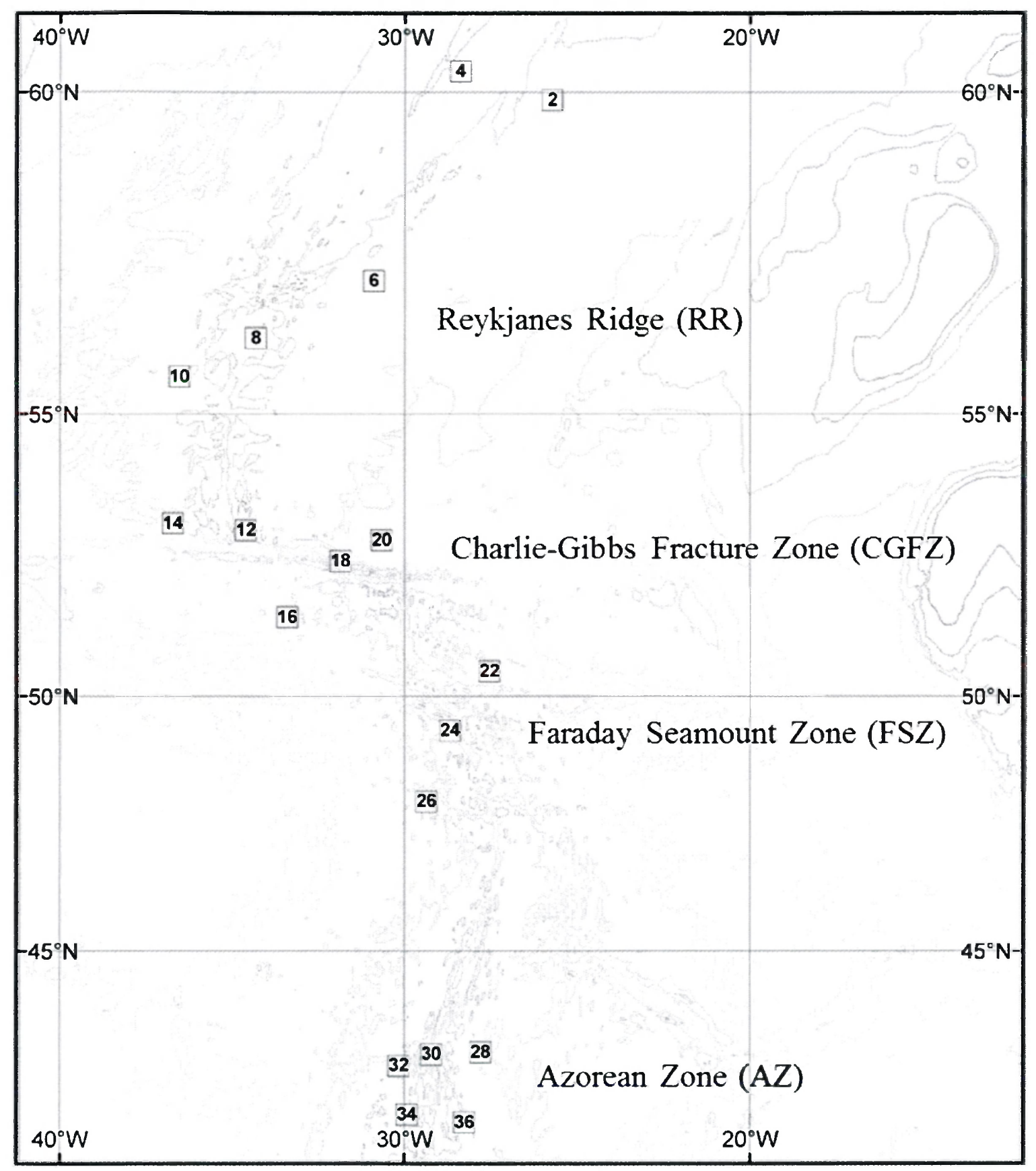

Figure 1. Trawl sampling stations at four ridge sections along the northern Mid-Atlantic Ridge from Iceland to the Azores during the 2004 R/V G.O. Sars MAR-ECO expedition. 


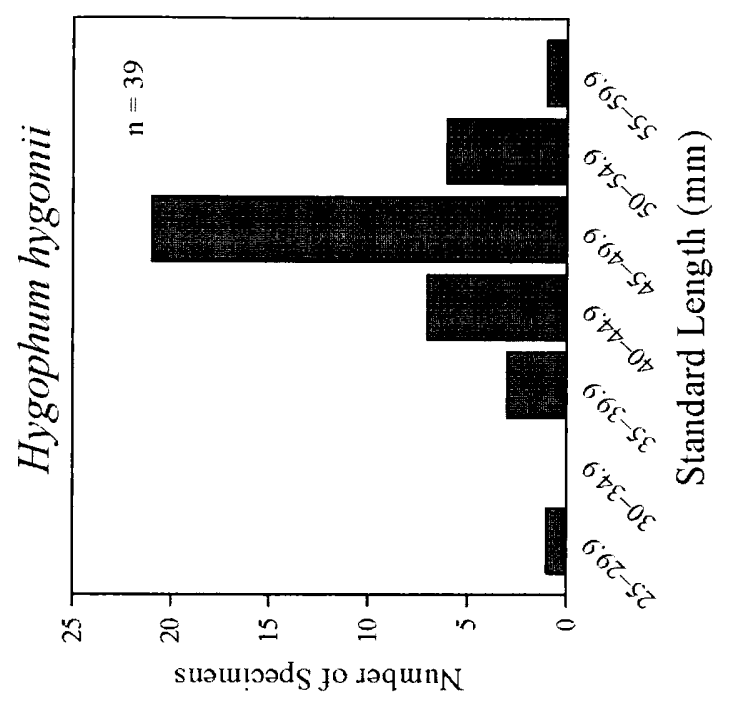

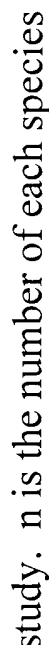

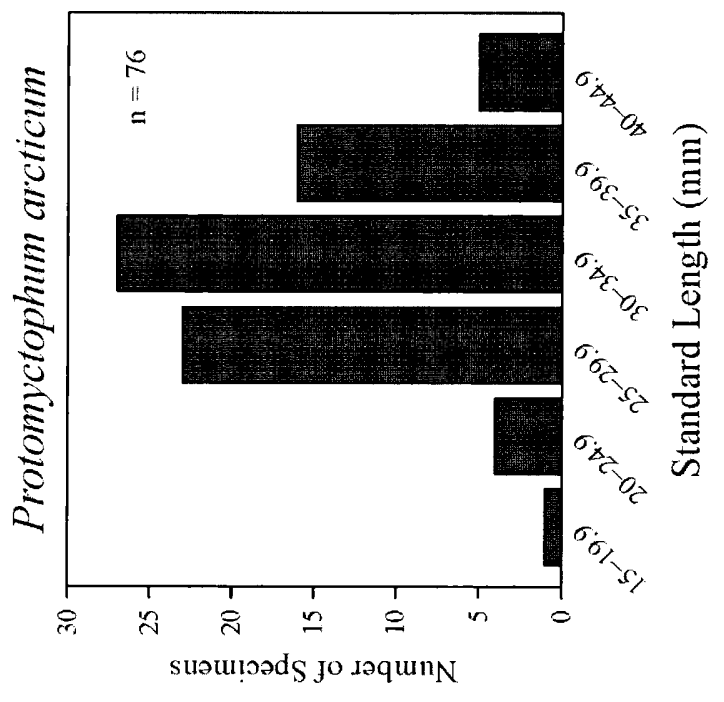

重

$\Xi$
0
0
0
0
.$\Xi$
0
0
0
0
0
0
0
0
0
0
0
0
0
0
0
0
0

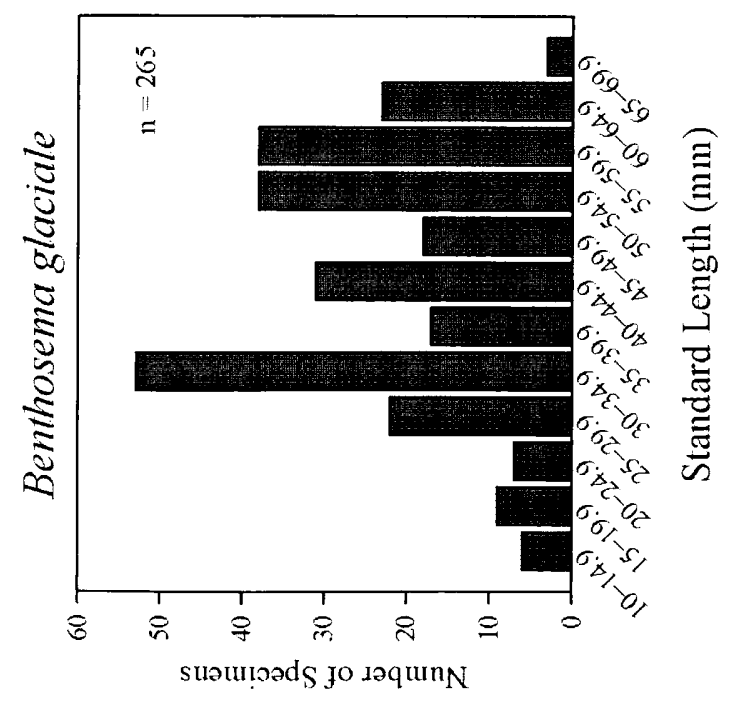

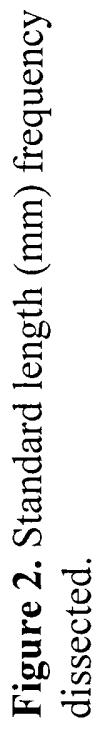


Figure 3. Cluster diagram (A) and scree plot (B) for Benthosema glaciale. The cluster diagram represents the relationships among the diet compositions of $5 \mathrm{~mm}$ size classes of B. glaciale. The scree plot was used to determine the number of clusters into which the size classes of B. glaciale should be grouped. 

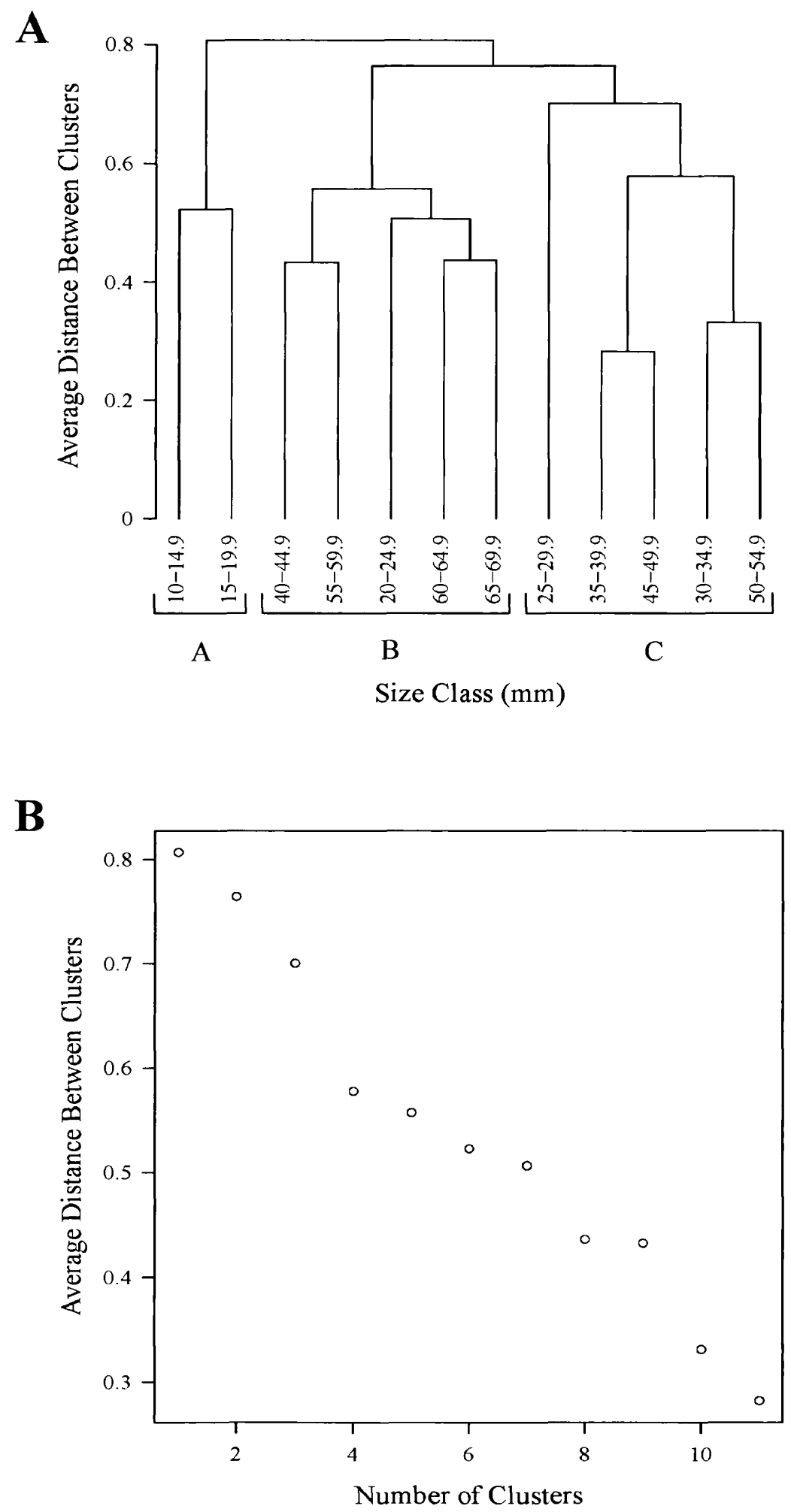
Figure 4. Canonical correspondence analysis biplot for Benthosema glaciale. Bolded labels represent the centroids for each level of the ridge section (Reykjanes Ridge, RR; Charlie-Gibbs Fracture Zone, CGFZ; Faraday Seamount Zone, FSZ; Azorean Zone, AZ) time of day, and depth zone (0-200 m, DZ 1; 200-750 m, DZ 2; 750-1500 m, DZ 3) explanatory variables. Points represent prey types in the diet. The canonical axes represent linear combinations of the explanatory variables. Ridge section and time of day were significant at $\alpha=0.05$. 


\section{Benthosema glaciale}

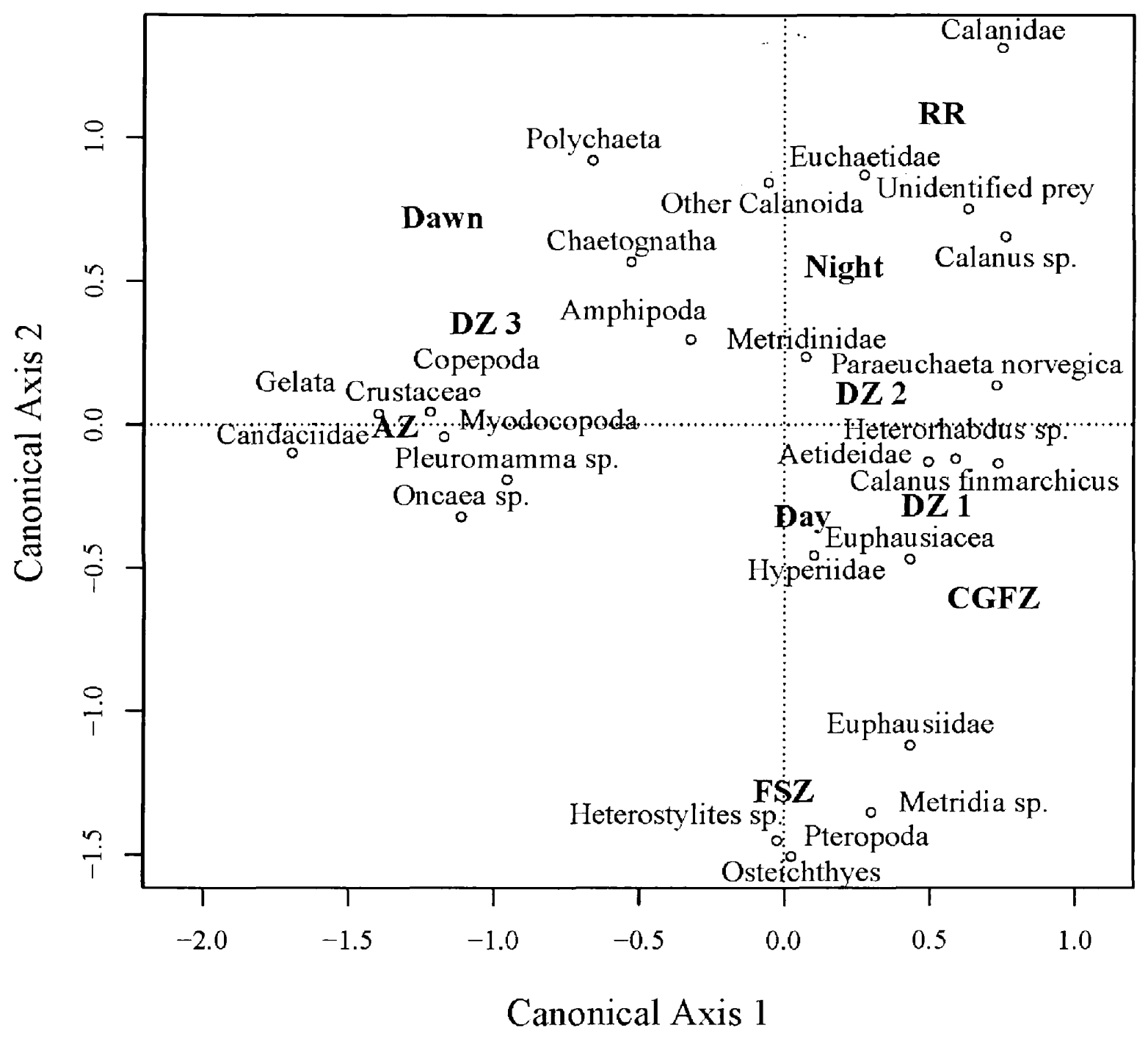


Figure 5. Diet composition (percent weight) of Benthosema glaciale presented by ridge section (A) and time of day (B). Error bars represent standard error of the percent weight values of each prey type in the diet of $B$. glaciale. $\mathrm{n}$ is the number of stomachs dissected from each ridge section or time of day. Note differences in scale of y axis for ridge sections and times of day. 

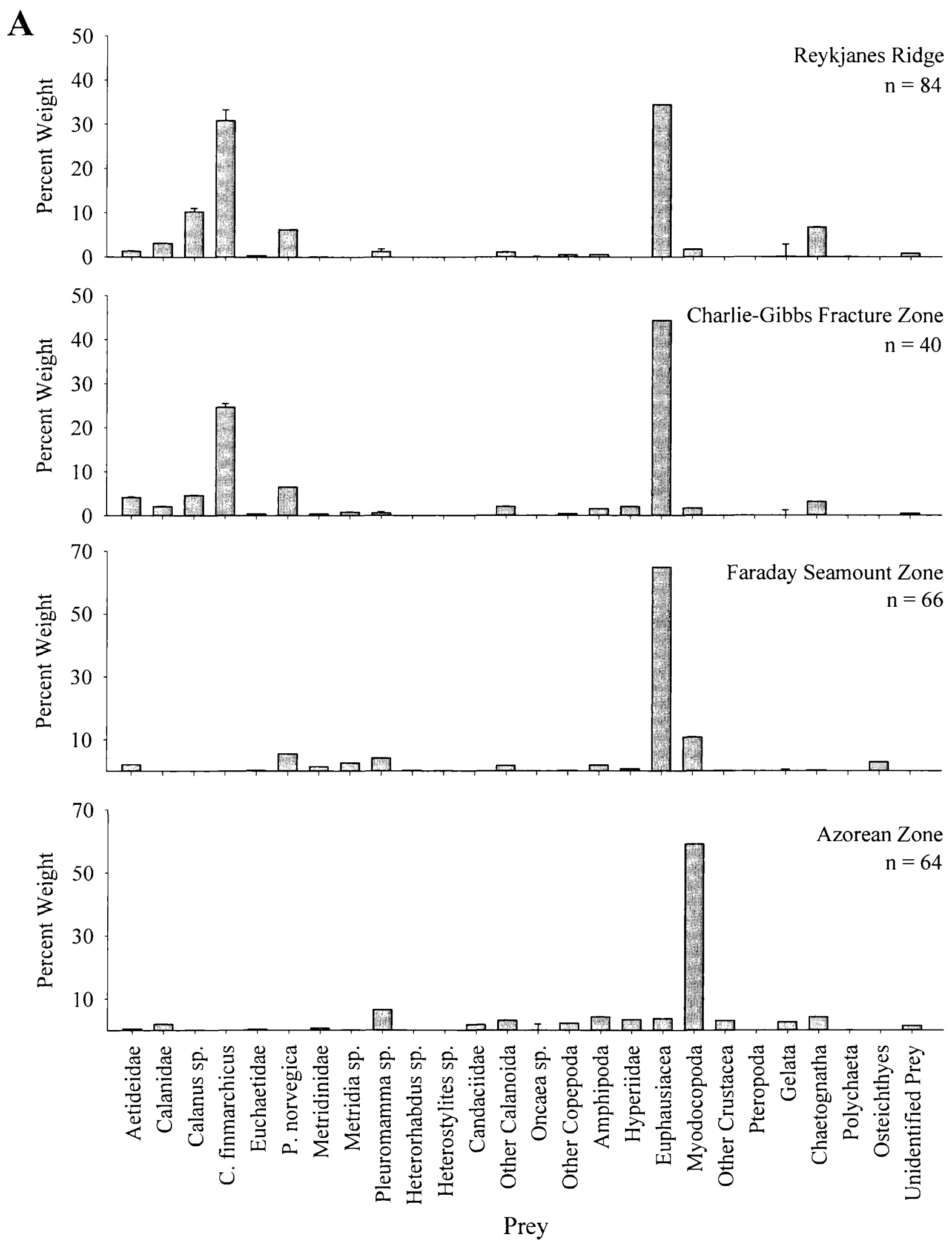

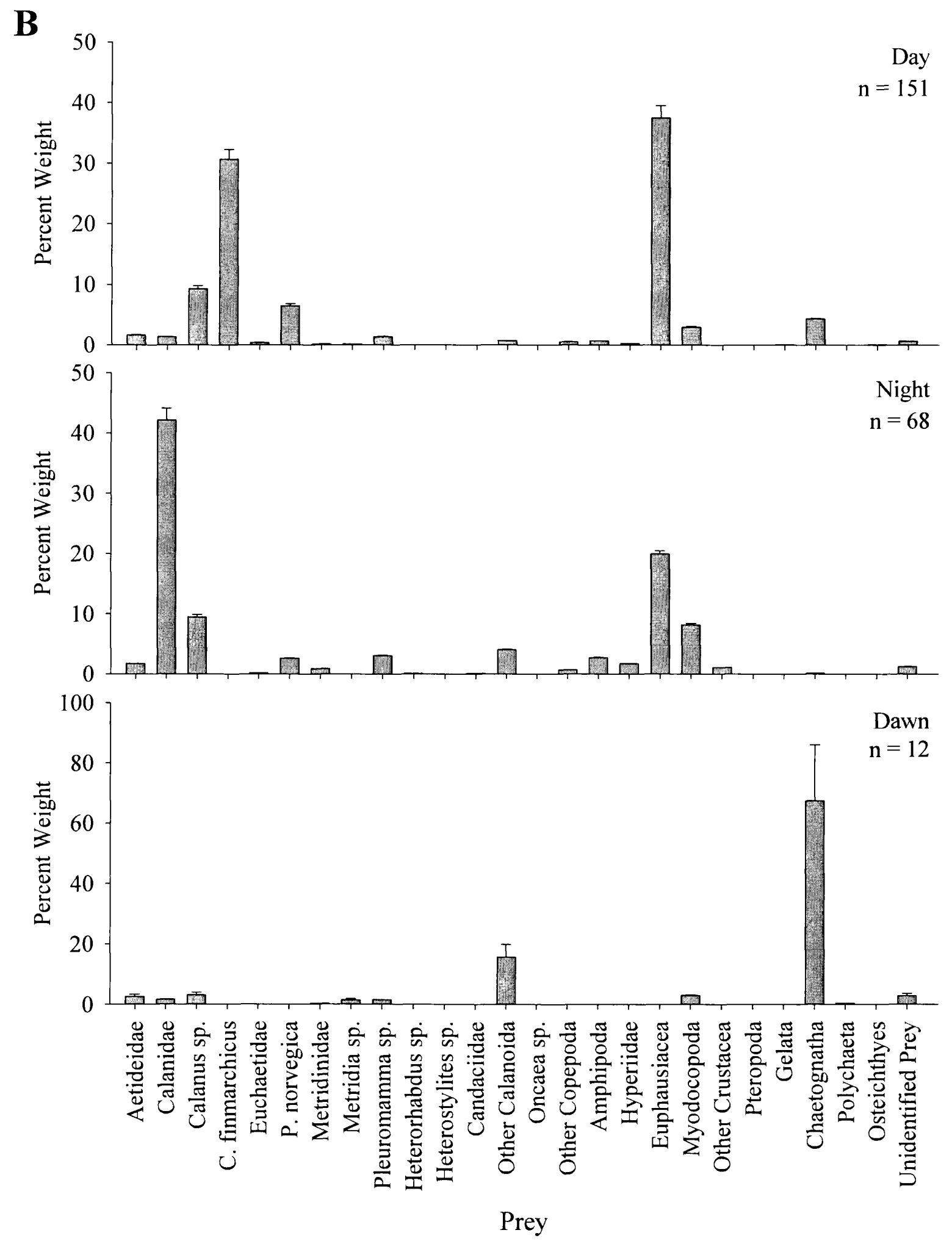

Figure 5. continued 


\section{Protomyctophum arcticum}

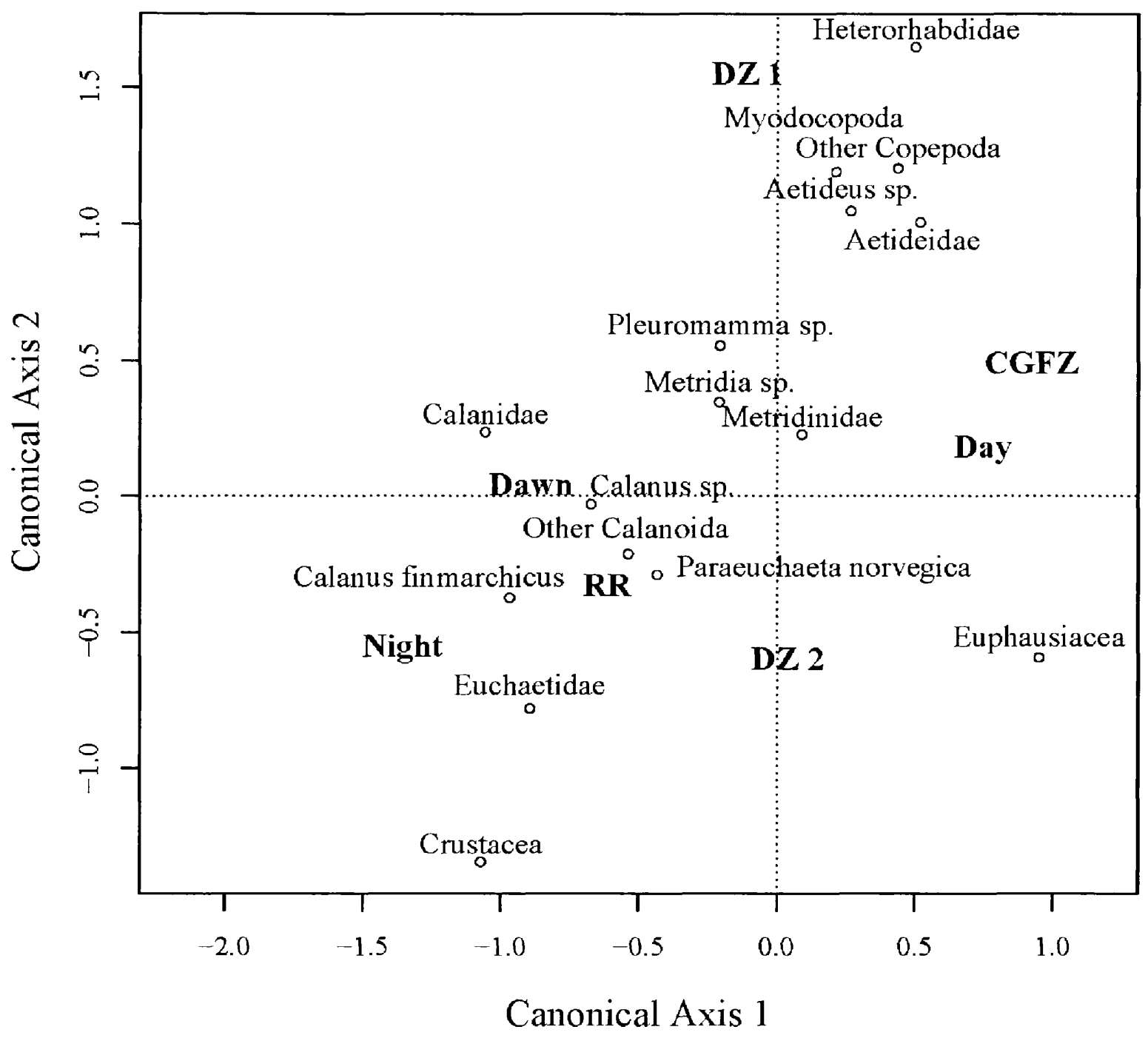

Figure 6. Canonical correspondence analysis biplot for Protomyctophum arcticum.

Explanatory variables include ridge section, time of day, and depth zone. Depth zone was significant at $\alpha=0.05$. For description of explanatory variables see Figure 4 . 


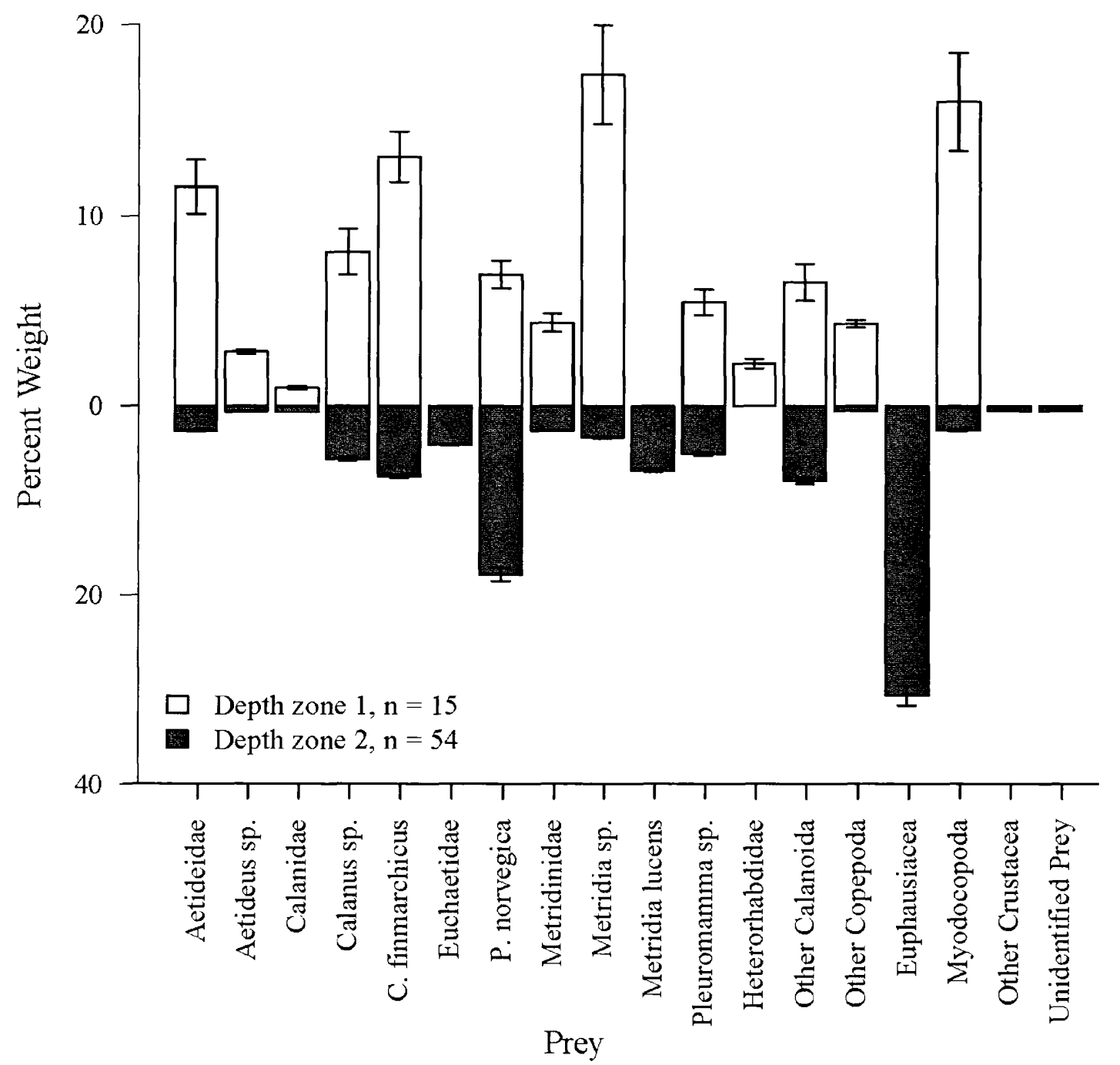

Figure 7. Diet composition (percent weight) of Protomyctophum arcticum, presented by depth zone (Depth zone 1, 0-200 m; Depth zone 2, 200-750 m). Error bars represent standard error of the percent weight values of each prey type in the diet of P. arcticum. n is the number of stomachs dissected from each depth zone. Note differences in scale of $y$ axis for depth zones 1 and 2 . 
Figure 8. Canonical correspondence analysis biplot for Benthosema glaciale (BG) and Protomyctophum arcticum (PA). A) includes all samples of each species. Ridge section and fish species were significant at $\alpha=0.05$. B) includes only samples of each species that were caught simultaneously. Fish species was significant at $\alpha=0.05$, time of day approached significance $(p=0.08)$. Explanatory variables include fish species, ridge section, time of day, and depth zone. For description of explanatory variables see Figure 4. 


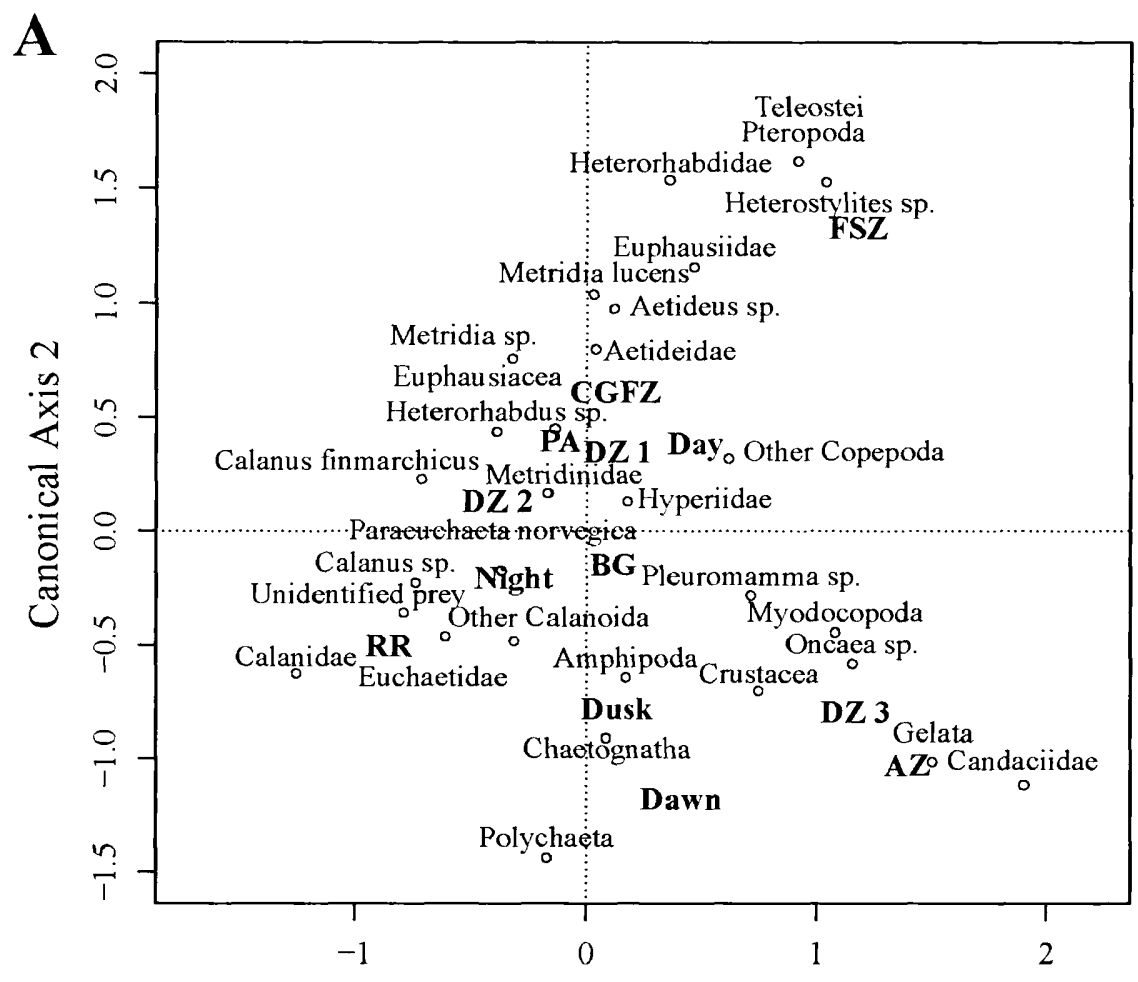

Canonical Axis 1

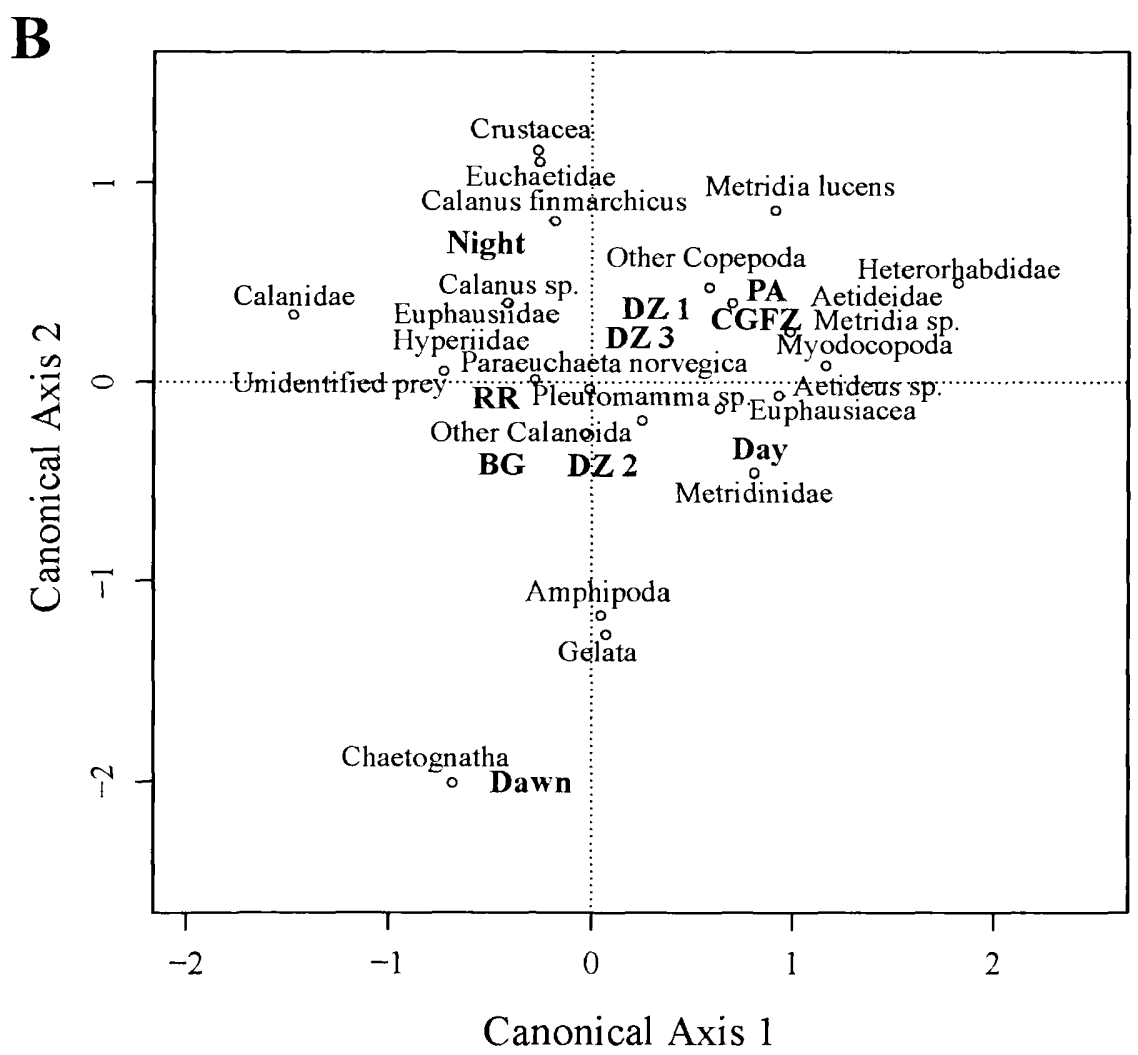


Vita

Jeanna Marie Hudson

Born August 24, 1986 in Alexandria, VA. Graduated from Culpeper High School in 2004. Earned a B.S. in Biology and a minor in Chemistry from Christopher Newport University in 2008. Worked as a research assistant with graduate student Lance Gardner, Center for Coastal Resource Management, and Virginia Sea Grant at the Virginia Institute of Marine Science (VIMS). Entered the Master's program in Fisheries Science at VIMS in 2009 under Dr. Tracey Sutton, and completed the program under co-advisors Drs. John Graves and Deborah Steinberg. 